\title{
Real Earnings Management, Habitually Meeting/Closely Beating Analysts' Forecasts and Firm Valuation
}

\author{
Jason Jiao \\ Bradley University
}

This paper values firms that utilize real earnings management (REM) to habitually meet/closely beat analysts' earnings forecasts (HabitMBE). The results suggest that in equilibrium, while HabitMBE firms in general enjoy a market premium, HabitMBE firms that use REM repeatedly are penalized by investors, and the market premium disappears. Not surprisingly, I find that HabitMBE firms that have already used REM repeatedly try to curtail its use. Another interesting finding is that analysts' downward forecast revision has a significantly negative effect on firms'valuation, which prior studies have not clearly documented.

Keywords: real earnings management, habitually meeting/marginally beating analysts' earnings forecasts, market valuation

\section{INTRODUCTION}

Real earnings management (REM) has gained much attention in the accounting literature, especially since Sarbanes-Oxley Act (SOX) 2002. Anecdotal, survey, and empirical evidences show that managers use REM to achieve financial reporting benchmarks. Benchmark is defined as a standard, a point of reference for measurement of performance. In this study, I examine the association between using REM to habitually meet/closely beat analysts' earnings expectations (HabitMBE) and firm valuation.

Incentives with penalties for failing to achieve pre-set benchmarks and rewards for meeting or beating them (step function) have been shown to induce higher levels of effort/skills, which improve performance, and in turn, create more value. Corporate managers are often evaluated and compensated based on whether they meet/beat certain earnings benchmarks (Antle and Smith 1986). Managers' compensation levels are usually contingent upon whether they reach different levels of industry-wide and economy-wide financial benchmarks (Healy, 1985). These compensation functions with steps at the benchmarks are referred to in the literature as "Bang-bang" contracts. Bang-bang contracts are shown to be optimal under many circumstances (Mirrlees, 1976; Demski and Feltham, 1978; Harris and Raviv, 1979).

When benchmarks reflect effort with little uncertainty, they induce higher levels of effort, which result in better performance. Investors reward better performance by attributing it to managers' higher levels of effort. In the context of a firm, the economic income - the economic value added - can be increased (stochastically) only with effort and is not subject to manipulation. However, economic income is not observable and therefore cannot be used for benchmarking purpose to induce higher levels of effort. The accounting earnings, which are typically used to proxy for managers' performance are, however, 
subject to managers' manipulation through earnings management that is not reflective of managers' effort. Therefore, investors may not rely solely on accounting earnings as benchmarks to evaluate managers' performance. In order to attribute accounting earnings properly to effort investors are interested in assessing the likelihood that the performance is achieved through earnings manipulation.

Earnings can be managed through accruals earnings management (AEM), REM, earnings expectation management, and other egregious non-GAAP methods. The enactment of SOX in 2002 has increased the scrutiny of auditors and regulators on AEM, which has made it costlier to use as an opportunistic management device (Brown and Pinello, 2007). As an alternative, managers have increased the usage of REM since SOX (Cohen et al., 2008). Managers' flexibility to use AEM to manage earnings is also restricted because accruals reverse and repeatedly applying AEM is not sustainable (Matsumoto, 2002). Unlike managers dealing with AEM, managers have direct control over operations to make real economic choices, with the full knowledge that economic choices are not subject to the scrutiny of the auditors and regulators (Gunny, 2010). There is evidence that managers take real economic actions to manage earnings (Graham et al., 2005). Given that REM is likely to irreversibly destroy long-term value, it is not surprising that there has been a significant focus on REM in the post-SOX period.

REM represents departures or deviations from normal operational practices, intended by managers to mislead some stakeholders so that certain earnings benchmarks are achieved (Roychowdhury, 2006). Due to information asymmetry, managers might have private information that they can credibly convey through signaling to the market by using REM. In this case, REM can be used occasionally to cross the benchmark to signal the capital market firms' foresight about better future performance. In some other cases, REM can be used opportunistically by the managers.

Managers can occasionally use REM to meet/closely beat benchmarks to jointly signal their private insight about better future performance to the market (Gunny, 2010). Investors and financial analysts can see through managerial myopic actions (Gunny, 2005). Bang-bang contracts are still optimal in this case based on the infrequent recourse to REM, where managers are rewarded for meeting/beating the benchmarks (Bartov et al., 2002; Gunny, 2010). If managers occasionally use REM to meet/beat earnings benchmarks, investors are still likely to attribute the signal to managers' higher levels of effort (Gunny, 2010). However, if managers habitually use REM to do so, the likelihood of investors' attributing the signal to effort will drop, and the likelihood of investors' attributing the signal to managers' opportunism will rise. In effect, while the market response to the occasional use of REM to meet/beat earnings expectations is positive as documented in the literature, I expect a reduction in that positive "reward" when managers use REM to persistently or habitually meet/closely beat analysts' earnings forecasts (HabitMBE). The literature is silent on whether and to what extent the investors look back at the historical use of REM to meet/closely beat analysts' earnings forecasts (MBE) in their valuation of the firm. This study addresses this empirical research question by examining the association between using REM to HabitMBE and firm valuation.

My choice of analysts' earnings forecast as the earnings benchmark is based on prior findings. Accounting literature documents several earnings benchmarks such as avoiding zero earnings, avoiding earnings decrease from previous quarter or year, and MBE (Burgstahler and Dichev, 1997; Degeorge et al., 1999; Burgstahler and Eames, 2006). Financial analysts are important information intermediaries whose reputation, and in fact, the value of their profession depends on their ability to forecast firms' future prospects. Investors rely heavily on analysts' forecasts about firms' earnings for their investment activities.

Analysts' earnings forecast as an earnings benchmark has been shown to be superior to time-series models in predicting earnings (Brown et al., 1987). Equally important, it cannot be directly manipulated by the managers. Not surprisingly, investors use analyst forecasts as benchmarks to assess managerial performance. Investors reward firms that meet/beat analysts' earnings forecasts (Bartov et al., 2002; Kasznik and McNichols, 2002) and penalize those that fail to do so (Skinner and Sloan, 2002). Managers also regard analysts' forecast as an important benchmark since their compensation and reputation in the executive labor market are often tied to whether they achieve the goal (Graham et al., 2005). 
This study aims to address a research question that has not been empirically addressed in existing literature. Capital markets reward firms that meet/beat analysts' forecasts, and penalize those that fail to do so. Prior research documents that even though the market seems to know that managers' goal is achieved through earnings management, it still rewards those managers. The markets also attribute the meeting/beating behavior as an indicator of better future earnings. However, the majority of accounting literature documents the value-destroying nature of REM. One explanation of why the market seems to deviate from the documented value reduction in the literature is that managers can use REM to signal firms' foresight about future performance (Gunny, 2010). The question therefore is when the value destruction by REM gets recognized by investors. This study contributes by providing the context habitual meeting/closely beating analysts' earnings expectations - when investors recognize such value reduction. In effect, this study provides insights about how and when the markets discipline managers who use REM to HabitMBE.

This study is also potentially valuable to regulators. Regulators have expressed their concerns about the expectation games played between corporate managers and financial analysts. Former SEC Chairman Arthur Levitt (1998) and former SEC commissioner Norman S. Johnson (1999) both addressed their concerns about management's pressure to meet/beat analysts' earnings forecasts. It seems that analysts are not effectively monitoring managers' actions, and managers are not exerting effort to improve performance (Sankaraguruswamy and Sweeney, 2005). The results of this study shed some light on these concerns.

Using annual data for the period of 1987 to 2011, inclusive, I examine the association between using REM to HabitMBE and firm valuation proxied for by Tobin's Q (TQ). I identify HabitMBE firms based on a frequency of at least $50 \%$ of times that they meet/beat analysts' forecasts by one cent in the immediate prior history. The starting base period is the period from 1987 to 1993, inclusive. I also identify habitual beating firms (HabitBEATERS) that beat analysts' forecasts by more than one cent at least $50 \%$ of the times in the immediate prior history. After controlling for non-REM HabitBEATERS, REM-using HabitBEATERS, AEM, analysts' downward forecast revision, size, growth, risk, and financial health, the results indicate that HabitMBE firms enjoy a significant premium; however, if they use REM to HabitMBE, the market punishes them and the premium vanishes. HabitMBE firms are bigger and more transparent, and they use less REM than that of the control group. The results also indicate that analysts' downward forecast revision has a significantly negative effect on firms valuation, which prior literature has not clearly documented.

I review the related literature in Section 2, develop the hypotheses in Section 3, describe the data sources, variable measurement, and research methodology in Section 4, present descriptive statistics and empirical results in Section 5, and provide concluding remarks in Section 6.

\section{LITERATURE REVIEW}

\section{Real Earnings Management}

Prior studies define real earnings management (REM) from different perspectives. Schipper (1989, p.92) defines REM together with AEM as

a purposeful intervention in the external financial reporting process, with the intention of obtaining some private gain....a minor extension of this definition would encompass 'real' earnings management, accomplished by timing investment or financing decision to alter reported earnings or some subset of it.

Fields et al. (2001) include REM in their definition of accounting choice. They state that managerial intent is key to the definition of real decisions made primarily for the purpose of affecting the accounting numbers. The example they provide is whether a firm reduces its $R \& D$ expenditures primarily in order to alter accounting disclosures or primarily because of lower expected future returns to the R\&D investment.

Roychowdhury (2006, p.337) defines real activities manipulation (REM in this paper) as 
departures from normal operational practices, motivated by managers' desire to mislead at least some stakeholders into believing certain financial reporting goals have been met in the normal course of operations. These departures do not necessarily contribute to firm value even though they enable managers to meet reporting goals. Certain activities manipulation methods, such as price discounts and reduction of discretionary expenditures, are possibly optimal actions in certain economic circumstances. However, if managers engage in these activities more extensively than is normal given their economic circumstances, with the objective of meeting/beating an earnings target, they are engaging in real activities manipulation.

\section{Analysts' Earnings Forecast as a Benchmark}

Analysts' earnings forecast is an important earnings benchmark (Degeorge et al., 1999; Dechow et al., 2003; Brown and Caylor, 2005; Burgstahler and Eames, 2006). Accounting earnings are somewhat in the direct control of corporate managers. Managers can manage accruals and/or take real actions to meet/beat last reporting period's earnings or to avoid a loss. However, financial analysts are independent information intermediaries. Their career hinges on the reputation and accuracy of their earnings forecasts. Matsumoto (2002) describe analysts' forecasts as a "simple, defensible heuristic." Brown et al. (1987) show that analysts' earnings forecast is superior to time-series models in predicting earnings. Therefore, analysts' earnings forecast is an important benchmark, less prone to management manipulation.

There is an abundance of accounting literature documenting managers taking actions to meet/beat analysts' earnings forecasts. However, there is little research dealing with managers taking real actions, or using REM to HabitMBE, and meeting/closely beating analysts' earnings forecasts has been labelled as earnings management behavior (e.g., Cheng et al., 2005; Roychowdhury, 2006).

For instance, Matsumoto (2002) demonstrates that firms MBE through AEM and management's downward analysts' forecast guidance. However, she does not consider the situation where managers apply REM to HabitMBE. Bartov et al. (2002) show that firms that meet/beat analysts' forecasts enjoy a market premium even considering the fact that management applies AEM and management's downward analysts' forecast guidance. They further demonstrate that habitual meeting/beating firms are rewarded by the capital market. However, their habitual meeting/beating firms include not only those that MBE, but also those that beat analysts' forecasts by big margins. In addition, they do not take REM into consideration.

Consistency in analysts' forecasts seems to be more important than accuracy. Kross et al. (2011) find that firms with more consistent pattern of meeting/beating analysts' forecasts provide more frequent and pessimistic management earnings forecasts. Hilary and Hsu (2013) find that more consistent analysts have greater ability to move stock prices. They also state that more consistent analysts are "less likely to be demoted to less prestigious brokerage houses, and are more likely to become All Stars." However, these studies do not consider either AEM or REM.

\section{REM can be Used to Meet/beat Earnings Benchmarks}

Management can use REM to meet/beat earnings benchmarks. Dechow et al. (2003) find that incomeincreasing AEM cannot sufficiently explain the earnings kinks arising from the significant difference between the number of too many small profit firms and the number of too few small loss firms documented by (Burgstahler and Dichev, 1997). Instead, Dechow et al. (2003) mention the possibility that managers may have applied REM to meet/beat earnings benchmarks, and empirical research has shown evidence that managers apply REM to meet/beat earnings benchmarks (Bartov, 1993; Roychowdhury, 2006; Gunny, 2010).

\section{Perspectives of REM}

There are mainly two perspectives toward REM. On one hand, the majority of accounting literature documents a value-destroying effect of REM. Evans and Sridhar (1996) state that managers can manage 
earnings through either AEM or REM to have some impact on their compensation. However, due to the reversal of accruals, manipulating earnings through REM will result in greater loss to shareholders. Bhojraj et al. (2009) examine the performance consequences of cutting discretionary expenses and managing accruals to beat analysts' forecasts. They find that firms that cut discretionary spending to beat analysts' forecasts are more likely to sacrifice long-term shareholder value. Cohen and Zarowin (2010) show that SEO firms exhibit some evidence of REM. The performance reduction due to REM is much worse than that due to AEM. The post-SEO economic underperformance reflects not only the effect of accrual reversals, but also the real consequences of REM.

On the other hand, managers may use REM to signal private information to financial statement users. REM is a way to signal firms' superior future performance. Beneish (2001) states that under the information perspective of earnings management, managerial discretion is a means for managers to reveal to investors their private expectations about the firm's future cash flows. Gul and Srinidhi (2002) find that managers of firms with greater investment opportunities use earnings management to signal future opportunities for growth. Gunny (2010) demonstrates that managers use REM to signal firms' brighter future performance. Specifically, she indicates that firms that use REM to just meet/closely beat zero earnings/growth feature significantly higher industry-adjusted one-year to three-year ahead ROA than non-REM bench firms. The results suggest that using REM to meet/closely beat certain benchmarks is not opportunistic, but it is consistent with the statement that it signals better future performance. However, Gunny (2010) uses accounting performance measures, not a market performance measure.

\section{HYPOTHESIS DEVELOPMENT}

REM can destroy firms' long-term value (Roychowhury, 2006), but accounting literature shows that using REM to occasionally MBE signals firms' brighter accounting performance (Gunny, 2010). Managers can have direct control over accounting performance, but very little control over analysts' earnings forecasts. Managers and analysts can play games to please each other to a certain degree (Sankaraguruswamy and Sweeney, 2005), but not to the point that the symbiosis relationship will destroy analysts' careers. Analysts and investors can see through managerial REM actions (Gunny, 2005). While using REM to occasionally MBE could signal firms' brighter future accounting performance (Gunny, 2010), utilizing REM to HabitMBE could convey negative signals to the capital markets and incur severe penalty to firms' value. Therefore, Hypothesis 1 is stated (in the alternative form) as follows:

H1: Ceteris paribus, there is a negative association between using REM to HabitMBE and firm valuation.

Prior Accounting literature documents that analysts tend to follow and cover large firms. Barth et al. (2001) document that large firms on average get more analysts' coverage, leading to more transparent firms. Due to limitations of AEM and the severity of being detected by independent auditors and the SEC, REM may become the makeshift of managers. However, Gunny (2005) shows that analysts and investors can see through managerial REM actions. Therefore, a firm is unlikely to persistently rely on REM to achieve the goal of meeting/closely beating analysts' earnings forecasts. Hypothesis 2 is stated in the alternative form as follows:

H2: HabitMBE Firms use less REM than that used by the control group including occasional MBE firms, occasional beating firms, and firms that miss analysts' forecasts.

\section{DATA, VARIABLE MEASUREMENT, AND METHODOLOGY}

Data

I collect the related data from two sources. According to Bhojraj et al. (2009) yearly data make more sense than quarterly data in the analysis of earnings management since majority of accruals adjustments 
occur in the fourth quarter, and quarterly reporting of R\&D and advertising expense is sparse. Therefore, I collect yearly data for this study. Financial data are from COMPUSTAT. As mentioned by Roychowdhury (2006), since CFO data were not available from COMPUSTAT before 1987, I collect the financial data for the period of 1987 through 2011. The Institutional Brokers' Estimate System (I/B/E/S) database provides the information for analysts' forecasts and actual earnings data.

One major concern about applying REM to meet/beat analysts' forecasts is that REM must be taken before the fiscal year-ends, and analysts' forecasts fluctuate as they become closer to the actual earnings announcements. Following Bhojraj et al. (2009), I collect the one-year ahead consensus analysts' forecasts of EPS that are forty-five to sixty days before the fiscal year-end, and the most recent consensus analysts' forecasts just before the earnings announcements. The forecasts that are forty-five to sixty days before the fiscal year-end are treated as the targets for managers to manage earnings. I take the difference between the actual EPS and the forecasts that are forty-five to sixty days before the fiscal year-ends as the earnings surprise figure.

Accounting literature documents that managers resort to different earnings management mechanisms concurrently (Badertscer, 2011; Zang, 2012). Therefore, I control for the effects of AEM and analysts' expectations management. Following Bhojraj et al. (2009) in order to avoid not capturing the effect of management's downward earnings forecast guidance, I take the difference between the final consensus analysts' forecast just before the earnings announcements and the forecasts forty-five to sixty days before the fiscal year-end as the earnings forecast revision. If the value is negative, I interpret this phenomenon as downward forecast guidance. After deleting missing values, I have a total number of observations from $\mathrm{I} / \mathrm{B} / \mathrm{E} / \mathrm{S}$ of 82,443 .

The COMPUSTAT database provides the other financial data needed for this study. Following Roychowdhury (2006), I reduce standard industrial classification (SIC) codes to the first two digits. I delete the utilities industries (SIC codes between 44 and 50) and the banks and financial institutions (SIC codes between 60 and 70) because their financial statements tend to be very different from those of other firms. After deleting missing values on needed variables, I have a total number of observations of 146,055 from COMPUSTAT.

The two data sets are merged to allow for further analyses. After deleting missing values and winsorizing at the 1 and 99 percentile on continuous variables, I have total observations of 29,355. Following Roychowdhury (2006), I estimate the models for normal or expected cash flow from operations (CFO), production costs, and discretionary expenditures by every year and industry. I also require at least 15 observations for each industry-year group. After imposing this restriction, I have total observations of 25,341 for the Fama-MacBeth estimation process, covering 3,725 firms and 509 industryyear groups.

The next step is to identify the habitual observations. To get a reasonable number of observations, I use a frequency of at least 50 percent to identify groups of interests. For HabitMBE group, they are the observations that have met/closely beaten analysts' forecasts based on the immediate prior meeting/beating history. The base starting evaluation period is 1987 - 1993, inclusive. For instance, based on the meeting/beating history for these seven years, if a firm meets or beats analysts' forecasts by one cent for at least 4 times, it will be identified as a HabitMBE in the next year, 1994, in this case. For the later years, the similar procedure applies until the end of the study period of 2011. The similar procedure follows for the identification of HabitBEATERS. After these steps, for the period of 1994 to 2011, inclusive, I have a total number of observations of 19,877 covering 3,324 firms, including 1,292 HabitMBE firm-year observations covering 171 firms, and 772 HabitBEATERS firm-year observations covering 172 firms.

\section{Variable Measurement}

For comparability and validity reasons, I follow prior studies to estimate AEM and REM measures. Following Jones (1991), I estimate normal levels of AEM, and discretionary accruals (DA) are the residuals of the following regression. I use DA as a control variable in testing my hypothesis. 
$T A_{t} / A_{t-1}=\alpha_{0}+\alpha_{1}\left(1 / A_{t-1}\right)+\alpha_{2}\left(S_{t} / A_{t-1}\right)+\alpha_{3}\left(P P E_{t} / A_{t-1}\right)+\varepsilon_{t}$

Following Roychowdhury (2006) I use the equations listed below to determine the REM measures.

$$
\begin{aligned}
& \operatorname{CFO}_{t} / A_{t-1}=\alpha_{0}+\alpha_{1}\left(1 / A_{t-1}\right)+\alpha_{2}\left(S_{t} / A_{t-1}\right)+\varepsilon_{t} \\
& \begin{aligned}
\text { PROD }_{t} / A_{t-1}=\alpha_{0} & +\alpha_{1}\left(1 / A_{t-1}\right)+\alpha_{2}\left(S_{t} / A_{t-1}\right)+\alpha_{3}\left(\Delta S_{t} / A_{t-1}\right) \\
& +\alpha_{4}\left(\Delta S_{t-1} / A_{t-1}\right)+\varepsilon_{t}
\end{aligned} \\
& \operatorname{DISEXP}_{t} / A_{t-1}=\alpha_{0}+\alpha_{1}\left(1 / A_{t-1}\right)+\alpha_{2}\left(S_{t-1} / A_{t-1}\right)+\varepsilon_{t}
\end{aligned}
$$

REM measures are the residuals from the equation (2), (3), and (4). In order to ease the interpretation of the results, I multiply the residuals from equation (2) and (4) by -1 to get the sign-adjusted REM measures for REM CFO and REM DISEXP, so that the higher the value, the higher the magnitude of REM, respectively. Following Gunny (2010), Cohen and Zarowin (2010), and Zang (2012), I create three aggregate measures of real earnings management. REM1 is the sum of sign-adjusted REM_DISEXP and REM_PROD, REM2 is the sum of sign-adjusted REM_DISEXP and REM_CFO, and REM is the sum of sign-adjusted REM_CFO, REM_DISEXP, and REM_PROD.

In order to capture the incremental effect of the REM on firm valuation, I create dummy variables for REM. DREM_CFO is equal to 1 if REM CFO is greater than zero, otherwise it is equal to zero. DREM_DISEXXP is equal to one if REM_DISEXP is greater than zero, otherwise it is equal to zero. DREM_PROD is equal to one if REM_PROD is greater than zero, otherwise it is equal to zero. The DREM 1 is the first aggregate dummy REM measure. It is equal to one if the sum of REM_DISEXP and REM_PROD is greater than zero, otherwise it is equal to zero. The DREM2 is the second aggregate dummy REM measure. It is equal to one if the sum of REM_DISEXP and REM_CFO is greater than zero, otherwise it is equal to zero. The DREM is the third aggregate dummy REM measure. It is equal to one if the sum of REM_CFO, REM_DISEXP, and REM_PROD is greater than zero, otherwise it is equal to zero.

The suspect firms are those that habitually meet/closely beat analysts' forecasts. Following Zang (2012), I identify HabitMBE firms as those that habitually meet/closely beat analysts' forecasts by one cent, and I identify HabitBEATERS as those that habitually beat analysts' forecasts by more than one cent.

\section{Methodology}

Since this study deals with the association between using REM to habitually meet/closely beat analysts' forecasts and firm valuation, the group of interest is the HabitMBE firms. To be consistent with prior literature, I also identify and specifically control for the HabitBEATERS. However, using the same frequency to denote "habitual" results in very few habitual losers. Therefore, the control group in this study consists of all other firm-year observations that do not belong to HabitMBE and HabitBEATERS, including occasional beating firms by big margin, occasional meeting/close beating firms, and losing firms.

Even though the control group consists of a myriad of categories of firm-year observations, the interpretation of the results should not be problematic. The intercept represents the average market value (TQ) of the control group. Since the control group consists of different categories of firm-year observations, the same firm could be listed in different categories, but each firm-year is unique, belonging to only one of the three categories: HabitMBE, HabitBEATERS, or Others.

In addition, the REM measures for HabitBEATERS firms may not be appropriate due to their specific characteristics. HabitBEATERS are strong performers by beating analysts' forecasts consistently by big margins. The REM measures may not be appropriate measures for this group of firms, because their optimum may have changed due to higher demand than that to other categories in this study. 
Following prior literature (Yermack, 1996; Anderson and Reeb, 2003), I use Tobin's Q as the market measure of firm valuation. Following Kaplan and Zingales (1997), I calculate Tobin' Q as market value of assets (book value of assets data \#AT + market value of common equity data \#PRCC_F x data \#CSHO - book value of common equity data \#CEQ - balance sheet deferred taxes data \#TXDB)/book value of assets data \#AT.

Following prior accounting literature (Zang, 2012, Gunny, 2010), I use the following regression to test H1. I control for the effects of concurrent abnormal accruals (DA), growth (market to book ratio, MTB), SIZE (log of total assets), leverage (LEV), and firms' financial health (Z_SCORE).

$$
\begin{aligned}
T Q_{t+1}=\beta_{0}+\beta_{1} & \text { HabitBEATERS }_{t}+\beta_{2} \text { HabitMBE }_{t}+\beta_{3} \text { DREM }_{t} \\
& +\beta_{4} \text { DREM }_{t} * \text { HabitBEATERS }_{t}+\beta_{5} \text { DREM }_{t} * \text { HabitMBE }_{t} \\
& +\beta_{6} \text { DA A }_{t}+\beta_{7} \text { DOWN }_{t}+\beta_{8} \text { SIZE }_{t-1}+\beta_{9} \text { MTB }_{t-1}+\beta_{10} \text { LEV V }_{t-1} \\
& +\beta_{11} Z_{-} \text {SCORE }_{t}+\varepsilon_{t}
\end{aligned}
$$

To test H2, I follow Gunny (2010) and use the following regression:

$$
\begin{aligned}
\text { REM }_{t}=\alpha_{0} & +\alpha_{1} \text { HabitBEATERS }_{t}+\alpha_{2} \text { HabitMBE }_{t}+\alpha_{3} \text { SIZE }_{t-1}+\alpha_{4} \text { MTB }_{t-1} \\
& +\alpha_{5} \text { ROA }_{t-1}+\varepsilon_{t}
\end{aligned}
$$

\section{EMPIRICAL RESULTS}

\section{Descriptive Statistics}

\begin{tabular}{|c|c|c|c|c|c|c|c|c|}
\hline & \multicolumn{2}{|c|}{$\mathrm{CFO} / \mathrm{A}_{\mathrm{t}-1}$} & \multicolumn{2}{|c|}{ DISEXP/A $\mathrm{A}_{\mathrm{t}-1}$} & \multicolumn{2}{|c|}{$\mathrm{PROD} / \mathrm{A}_{\mathrm{t}-1}$} & \multicolumn{2}{|c|}{ Accruals/ $\mathrm{A}_{\mathrm{t}-1}$} \\
\hline Intercept & $\begin{array}{l}0.0693 \\
(23.22)\end{array}$ & $* * *$ & $\begin{array}{l}0.1321 \\
(17.75)\end{array}$ & $* * *$ & $\begin{array}{l}-0.1792 \\
(-27.82)\end{array}$ & $* * *$ & $\begin{array}{l}-0.0315 \\
(-15.55)\end{array}$ & $* * *$ \\
\hline $1 / A_{t-1}$ & $\begin{array}{r}-2.2377 \\
(-9.02)\end{array}$ & $* * *$ & $\begin{array}{l}4.6339 \\
(11.31)\end{array}$ & $* * *$ & $\begin{array}{r}-0.8187 \\
(-1.75)\end{array}$ & $*$ & $\begin{array}{r}0.0763 \\
(0.49)\end{array}$ & \\
\hline$S_{t} / A_{t-1}$ & $\begin{array}{l}0.0352 \\
(13.95)\end{array}$ & $* * *$ & & & $\begin{array}{r}0.8067 \\
(133.25)\end{array}$ & $* * *$ & & \\
\hline$\Delta \mathrm{S}_{\mathrm{t}} / \mathrm{A}_{\mathrm{t}-1}$ & $\begin{array}{r}0.0549 \\
(9.47)\end{array}$ & $* * *$ & & & $\begin{array}{r}-0.0503 \\
(-3.97)\end{array}$ & $* * *$ & $\begin{array}{l}0.0583 \\
(12.21)\end{array}$ & $* * *$ \\
\hline$\Delta \mathrm{S}_{\mathrm{t}-1} / \mathrm{A}_{\mathrm{t}-1}$ & & & & & $\begin{array}{r}-0.0308 \\
(-2.75)\end{array}$ & $* * *$ & & \\
\hline $\mathrm{S}_{\mathrm{t}-1} / \mathrm{A}_{\mathrm{t}-1}$ & & & $\begin{array}{l}0.1459 \\
(25.27)\end{array}$ & $* * *$ & & & & \\
\hline $\mathrm{PPE}_{\mathrm{t}} / \mathrm{A}_{\mathrm{t}-1}$ & & & & & & & $\begin{array}{l}-0.0495 \\
(-18.04)\end{array}$ & $* * *$ \\
\hline
\end{tabular}

Table 1 presents the Fama-MacBeth regression parameter estimates from Jones (1991) and Roychowdhury (2006). These coefficients in Table 1 are the mean of the estimates from Fama-MacBeth regressions. Most of the coefficients are consistent with those from Roychowdhury (2006).

TABLE 1

\section{FAMA-MACBETH REGRESSION PARAMETER ESTIMATION}

This table presents the results from Fama-MacBeth estimation. The total observations for this step are 25,341. The dependent variables are cash flow from operations (CFO) deflated by total assets at year t-1, $A_{t-1}$, discretionary expense (DISEXP) deflated by total assets at year t-1, production costs (PROD) deflated by total assets at year t-1, 
and total accruals (TA) deflated by total assets at year t-1, where PROD is the sum of costs of goods sold and the change in inventories, discretionary expense are the sum of advertising expense, research and development expense, and selling, general, and administrative expense, and TA equals the difference between net income and CFO. St is the net sales at year $\mathrm{t}, \triangle S_{t}$ is the change in net sales at year $\mathrm{t}$, and $\triangle S_{t-1}$ is the change in net sales at year $\mathrm{t}-1 . P P E_{\mathrm{t}}$ is the gross property, plant, and equipment at year t. There are 509 separate industry-years over the period of $1987-$ 2011.

Table 2 presents descriptive statistics for the entire sample covering the period of 1987 through 2011, including 3,725 firms. These values are comparable to those in Roychowdhury (2006). As noted in Table 2 , the mean of total assets is $\$ 1.56$ billion, with a median of about $\$ 330$ million. The mean of the sales is about $\$ 1.55$ billion with a median of about $\$ 360$ million. The mean of total accruals is about a negative five percent of total assets. The average CFO is about 10.5 percent of total assets. The mean of DISEXP is about 41 percent of total assets, and the mean of PROD is about 84 percent of total assets. The means of all three individual REM measures are all zeroes. The median of REM_CFO is -0.0003 , the median of REM_DISEXP is 0.0212, and the median of REM_PROD is 0.0091 .

TABLE 2

DESCRIPTIVE STATISTICS

\begin{tabular}{lrrrrrr} 
Variable & N & Mean & Median & Std Dev & $\begin{array}{r}\text { Lower } \\
\text { Quartile }\end{array}$ & $\begin{array}{r}\text { Upper } \\
\text { Quartile }\end{array}$ \\
\hline AT & 25341 & 1561.41 & 329.87 & 3685.91 & 110.60 & 1202.43 \\
SALE & 25341 & 1552.15 & 361.49 & 3546.85 & 116.76 & 1221.98 \\
ACCR/AT & 25341 & -0.0524 & -0.0505 & 0.0878 & -0.0937 & -0.0096 \\
CFO/AT & 25341 & 0.1051 & 0.1061 & 0.1086 & 0.0525 & 0.1634 \\
DISEXP/AT & 25341 & 0.4085 & 0.3389 & 0.2980 & 0.1914 & 0.5542 \\
PROD/AT & 25341 & 0.8437 & 0.7147 & 0.6049 & 0.4155 & 1.1148 \\
REM_CFO & 25328 & 0.0000 & -0.0003 & 0.0935 & -0.0507 & 0.0493 \\
REM_DISEXP & 25328 & 0.0000 & 0.0212 & 0.2188 & -0.0928 & 0.1268 \\
REM_PROD & 25086 & 0.0000 & 0.0091 & 0.1780 & -0.0906 & 0.1003 \\
REM1 & 25086 & 0.0003 & 0.0319 & 0.3692 & -0.1693 & 0.2134 \\
REM2 & 25328 & 0.0000 & 0.0229 & 0.2354 & -0.1085 & 0.1401 \\
REM & 25086 & 0.0002 & 0.0312 & 0.3970 & -0.1926 & 0.2314 \\
DA & 25328 & 0.0000 & 0.0032 & 0.0744 & -0.0338 & 0.0386 \\
TQ & 24035 & 1.9533 & 1.5356 & 1.3486 & 1.1608 & 2.2559 \\
ROA & 25341 & 0.0527 & 0.0613 & 0.1124 & 0.0169 & 0.1069 \\
SIZE & 25341 & 6.0609 & 5.9739 & 1.7913 & 4.7535 & 7.2654 \\
MTB & 25341 & 2.8391 & 2.1300 & 2.4039 & 1.3958 & 3.4072 \\
LEV & 25341 & 0.2055 & 0.1739 & 0.1952 & 0.0220 & 0.3223 \\
Z_SCORE & 25341 & 2.3534 & 2.3920 & 1.5005 & 1.5960 & 3.2005 \\
DOWN & 25341 & 0.3084 & 0.0000 & 0.4619 & 0.0000 & 1.0000 \\
\hline See AppEnX & & & & &
\end{tabular}

See Appendix for variable definition. 
The three aggregate measures of REM are still close to zeroes, but the medians are about 2 to 3 percent of the total assets higher than expected industry-year average, suggesting the usage of incomeincreasing REM. DA has an average of zero and a median of 0.0032 , meaning the average DA is about 0.32 percent of total assets, higher than the industry-year average. The average TQ is 1.95, with a median of 1.54. The average ROA is 5.27 percent, with a median of 6.13 percent. The SIZE is measured as the natural $\log$ of market value of equity. The mean is 6.06 (about $\$ 428$ million of market value of equity), with a median of 5.97 (about $\$ 392$ million of market value of equity). The MTB has a mean of 2.84, with a median of 2.13. The mean of LEV is 0.21 , with a median of 0.17 . The mean of Z_SCORE is 2.35 , with a median of 2.39, above the cutoff point (1.81, Altman, 2000) of being healthy firms.

Table 3 presents the correlation matrix of variables for the entire sample of 25,341 firm-year observation with 3,725 firms. TA, SALE, and TQ are significantly positively associated with ROA. It appears that AT and SALE are significantly negatively associated with REM_CFO. It seems that AT is positively associated with all the other five REM measures. AT and SALE are also positively associated with MTB and LEV, but AT is negatively associated with Z_SCORE, and SALE is not. 


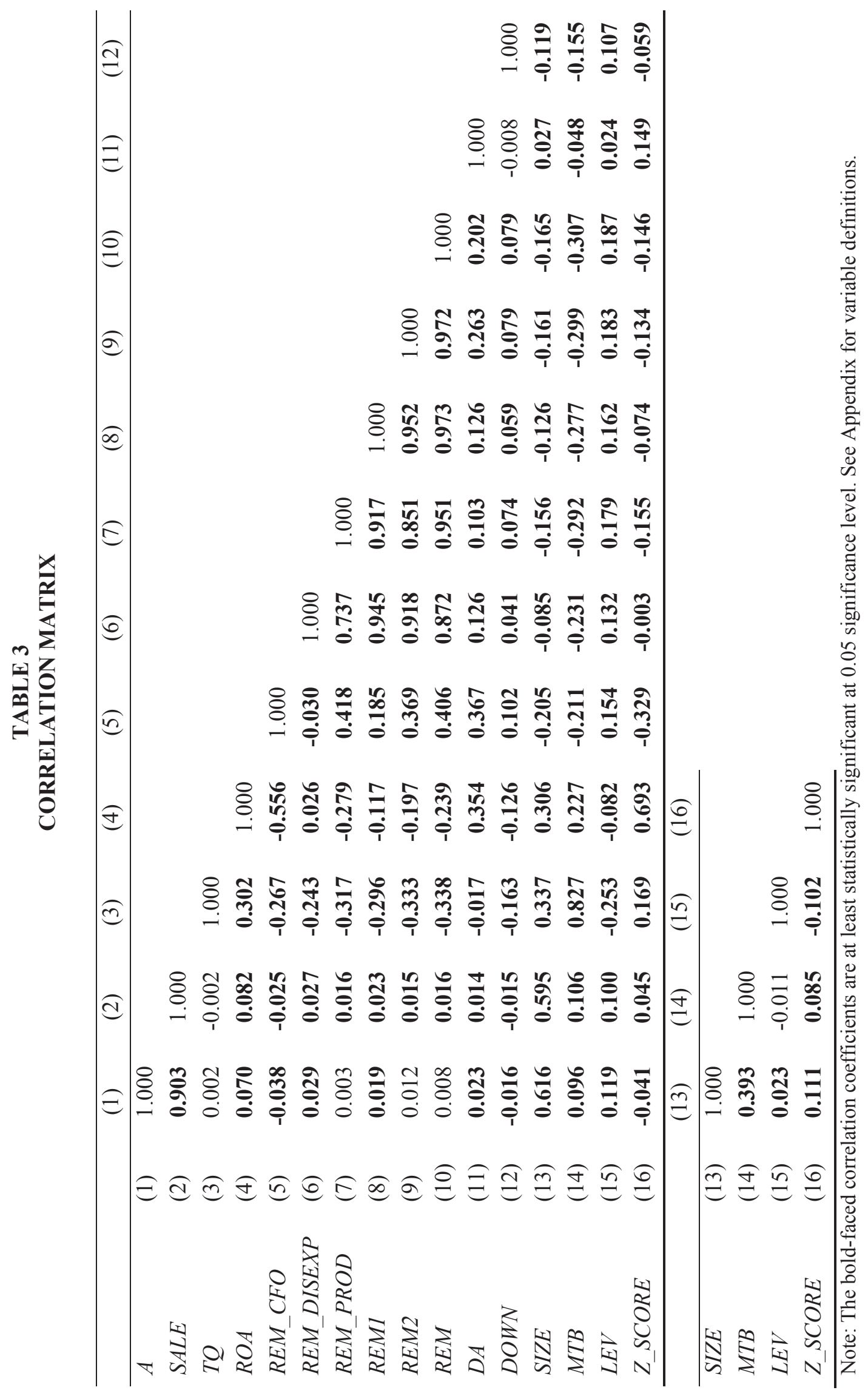


TQ is significantly negatively associated with all REM measures, implying that the capital market will penalize firms that engage in REM activities. TQ is significantly positively associated with SIZE, MTB, and Z_SCORE, but it is significantly negatively associated with LEV. Accounting performance measure ROA is significantly negatively associated with five of the six REM measures except REM_DISEXP. All REM measures are significantly positively associated with DA, implying that managers use AEM and REM concurrently, but all REM measures are significantly negatively associated with SIZE. All REM measures are also significantly negatively associated with MTB and Z_SCORE, but they are all significantly positively associated with LEV, suggesting high leverage firms engage in REM to avoid debt covenant violations.

Worth mentioning is the relation between TQ and DOWN. It appears that TQ is significantly negatively associated with DOWN, indicating that the capital market will assign some penalty to firms whose earnings forecasts analysts keep adjusting downward.

Table 4 shows the yearly distribution of HabitBEATERS and HabitMBE groups. Since I use the period of 1987 through 1993 as the base evaluation period for identification of HabitMBE and HabitBEATERS, the year reported in this table starts from 1994.

TABLE 4

YEARLY DISTRIBUTION OF HABITBEATERS AND HABITMBE

\begin{tabular}{rrrrrrr}
\multicolumn{4}{c}{ HabitBEATERS } & \multicolumn{3}{c}{ HaibtMBE } \\
\hline Year & Obs. & Freq. & Freq. & Obs. & Freq. & Freq. \\
\hline 1994 & 116 & 0.15 & 0.15 & 127 & 0.10 & 0.10 \\
1995 & 69 & 0.09 & 0.24 & 89 & 0.07 & 0.17 \\
1996 & 94 & 0.12 & 0.36 & 112 & 0.09 & 0.25 \\
1997 & 55 & 0.07 & 0.43 & 85 & 0.07 & 0.32 \\
1998 & 70 & 0.09 & 0.52 & 97 & 0.08 & 0.39 \\
1999 & 44 & 0.06 & 0.58 & 77 & 0.06 & 0.45 \\
2000 & 46 & 0.06 & 0.64 & 84 & 0.07 & 0.52 \\
2001 & 24 & 0.03 & 0.67 & 65 & 0.05 & 0.57 \\
2002 & 35 & 0.05 & 0.72 & 79 & 0.06 & 0.63 \\
2003 & 25 & 0.03 & 0.75 & 63 & 0.05 & 0.68 \\
2004 & 31 & 0.04 & 0.79 & 75 & 0.06 & 0.74 \\
2005 & 24 & 0.03 & 0.82 & 61 & 0.05 & 0.78 \\
2006 & 30 & 0.04 & 0.86 & 62 & 0.05 & 0.83 \\
2007 & 20 & 0.03 & 0.88 & 50 & 0.04 & 0.87 \\
2008 & 26 & 0.03 & 0.92 & 48 & 0.04 & 0.91 \\
2009 & 20 & 0.03 & 0.94 & 42 & 0.03 & 0.94 \\
2010 & 25 & 0.03 & 0.98 & 46 & 0.04 & 0.98 \\
2011 & 18 & 0.02 & 1.00 & 30 & 0.02 & 1.00 \\
\hline Total & 772 & & & 1292 & & \\
\hline
\end{tabular}

See Appendix for variable definitions.

On average, in the earlier years there are more observations in both categories. For instance, in year 1994, based on the prior meeting/beating history (at least 4 times) in the period of 1987 - 1993, there are 116 firms identified as HabitBEATERS, and 127 firms identified as HabitMBE. In year 2011, based on the prior meeting/beating history (at least 12 times) of firms in the period of 1987 to 2010, there are 18 firms identified as HabitBEATERS, and 30 firms identified as HabitMBE, respectively. 
Table 5 presents the Frequency distribution of HabitBEATERS and HabitMBE by industries based on 2-digit Standard Industrial Codification (SIC) code. Certain industries have more observations in the two categories identified as groups of interests. For example, in the HabitBEATERS category, SIC 35 (Industrial Machinery and Equipment) has the most observations of 109. The other groups that have many observations are SIC 36 (Electronic \& Other Electric Equipment), SIC 27 (Printing \& Publishing), SIC 38 (Instruments \& Related Products), and SIC 37 (Transportation Equipment). Based on the classification by the U.S. Department of Labor, all these sub-industries belong to the MANUFACTURING group.

TABLE 5

INDUSTRY DISTRIBUTION OF HABITBEATERS AND HAIBTMBE

\begin{tabular}{|c|c|c|c|c|c|c|c|}
\hline \multirow[b]{3}{*}{ SIC } & \multirow[b]{3}{*}{ Industry } & \multicolumn{6}{|c|}{$1994-2011$} \\
\hline & & \multicolumn{3}{|c|}{ HabitBEATERS } & \multicolumn{3}{|c|}{ HabitMBE } \\
\hline & & Obs. & Freq. & Cum. Freq. & Obs. & Freq. & Cum. Freq. \\
\hline 13 & Oil \& Gas Extraction & 34 & 0.044 & 0.04 & 4 & 0.003 & 0.003 \\
\hline 20 & Food \& Kindred Products & 27 & 0.035 & 0.08 & 119 & 0.092 & 0.095 \\
\hline 22 & Textile Mill Products & 8 & 0.010 & 0.09 & 0 & 0.000 & 0.095 \\
\hline 23 & Apparel \& Other Textile Products & 7 & 0.009 & 0.10 & 9 & 0.007 & 0.102 \\
\hline 25 & Furniture \& Fixtures & 5 & 0.006 & 0.10 & 0 & 0.000 & 0.102 \\
\hline 26 & Paper \& Allied Products & 52 & 0.067 & 0.17 & 0 & 0.000 & 0.102 \\
\hline 27 & Printing \& Publishing & 71 & 0.092 & 0.26 & 8 & 0.006 & 0.108 \\
\hline 28 & Chemical \& Allied Products & 65 & 0.084 & 0.35 & 187 & 0.145 & 0.253 \\
\hline 30 & Rubber \& Misc. Plastic Products & 16 & 0.021 & 0.37 & 23 & 0.018 & 0.271 \\
\hline 33 & Primary Metal Industries & 55 & 0.071 & 0.44 & 17 & 0.013 & 0.284 \\
\hline 34 & Fabricated Metal Products & 46 & 0.060 & 0.50 & 2 & 0.002 & 0.286 \\
\hline 35 & Industrial Machinery \& Equipment & 109 & 0.141 & 0.64 & 159 & 0.123 & 0.409 \\
\hline 36 & $\begin{array}{l}\text { Electronic \& Other Electric } \\
\text { Equipment }\end{array}$ & 89 & 0.115 & 0.76 & 177 & 0.137 & 0.546 \\
\hline 37 & Transportation Equipment & 66 & 0.085 & 0.84 & 69 & 0.053 & 0.599 \\
\hline 38 & Instruments \& Related Products & 71 & 0.092 & 0.93 & 193 & 0.149 & 0.748 \\
\hline 39 & Misc. Manufacturing Industries & 1 & 0.001 & 0.94 & 7 & 0.005 & 0.754 \\
\hline 54 & Food Stores & 3 & 0.004 & 0.94 & 0 & 0.000 & 0.754 \\
\hline 56 & Apparel \& Accessory Stores & 8 & 0.010 & 0.95 & 12 & 0.009 & 0.763 \\
\hline 58 & Eating \& Drinking Places & 0 & 0.000 & 0.95 & 51 & 0.039 & 0.803 \\
\hline 59 & Misc. Retail & 24 & 0.031 & 0.98 & 40 & 0.031 & 0.834 \\
\hline 73 & Business Services & 15 & 0.019 & 1.00 & 188 & 0.146 & 0.979 \\
\hline 79 & Amusement \& Recreation Services & 0 & 0.000 & 1.00 & 1 & 0.001 & 0.980 \\
\hline 80 & Health Services & 0 & 0.000 & 1.00 & 10 & 0.008 & 0.988 \\
\hline \multirow[t]{2}{*}{87} & $\begin{array}{l}\text { Engineering \& Management } \\
\text { Services }\end{array}$ & 0 & 0.000 & 1.00 & 16 & 0.012 & 1.000 \\
\hline & Total & 772 & & & 1,292 & & \\
\hline
\end{tabular}

See Appendix for variable definitions. 
For the HabitMBE category, SIC 38 (Instruments \& Related Products) has the most observations of 193. The other groups that have many observations are SIC 20 (Food \& Kindred Products), 119 observations, SIC 28 (Chemical \& Allied Products), 187 observations, SIC 35 (Industrial Machinery and Equipment), 159 observations, and SIC 36 (Electronic \& Other Electric Equipment), 177 observations. Based on the classification by the U.S. Department of Labor, all these sub-industries belong to the MANUFACTURING group. Different from HabitBEATERS category, HabitMBE has one SIC group that has many observations, SIC 73 (Business Services), 188 observations.

Table 6 presents the comparison of the three categories: HabitBEATERS, HabitMBE, and Others (the control group). From the size point of view (AT, SALE, and SIZE), HabitMBE firms are the largest among the three categories, with HabitBEATERS in the middle in all cases. In the case of accounting performance measure ROA, HabitMBE firms are the best performers, and the second best are the HabitBEATERS. For market performance measures, HabitMBE firms have the highest TQ and the highest MTB, but the HabitBEATERS have the lowest among all three groups. In terms of LEV, HabitMBE firms seem to be the least risky, and the HabitBEATERS are the most risky. In terms of financial health of firms, HabitMBE are the financially healthiest, and the HabitBEATERS are the second healthiest. 


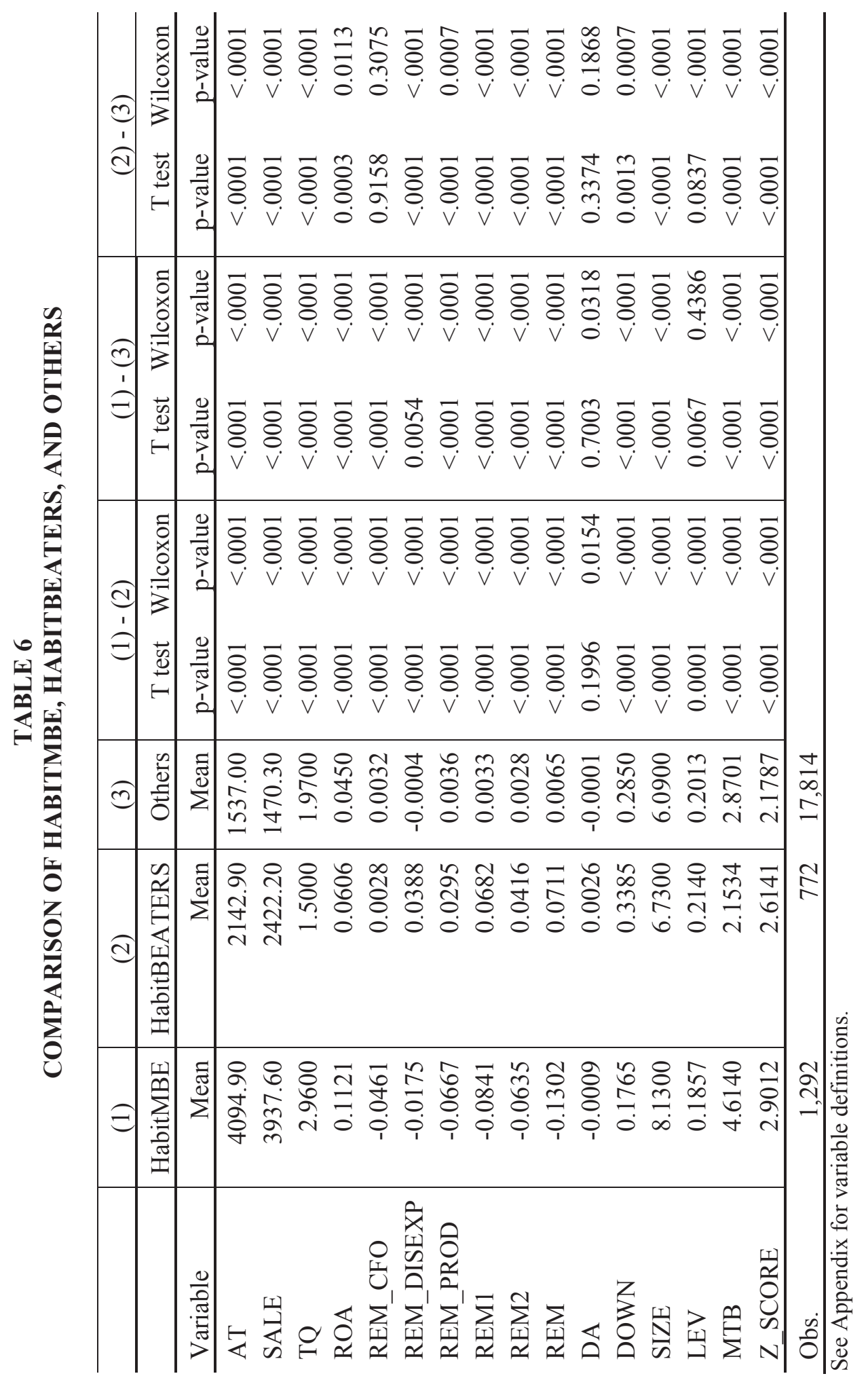


Substantiating Hypothesis 2, it appears, in Table 6, that HabitMBE firms have the lowest REM magnitude of all three categories, and they are all below the industry-year average (negative values). However, except REM_CFO measure, HabitBEATERS have the highest REM magnitude, and they are all above the industry-year average (positive). Similarly, HabitBEATERS firms have the highest value in DA (0.0026), but the differences between any two of the three categories are largely not statistically significant.

\section{Empirical Results}

Table 7 presents result of Hypothesis 1 using Ordinary Least Squares (OLS) regression. Most variables have signs consistent with the expectations except HabitBEATERS $\left(\beta_{1}\right)$ and DREM * HabitBEATERS $\left(\beta_{5}\right)$, the explanations of which are beyond the scope of this study. 


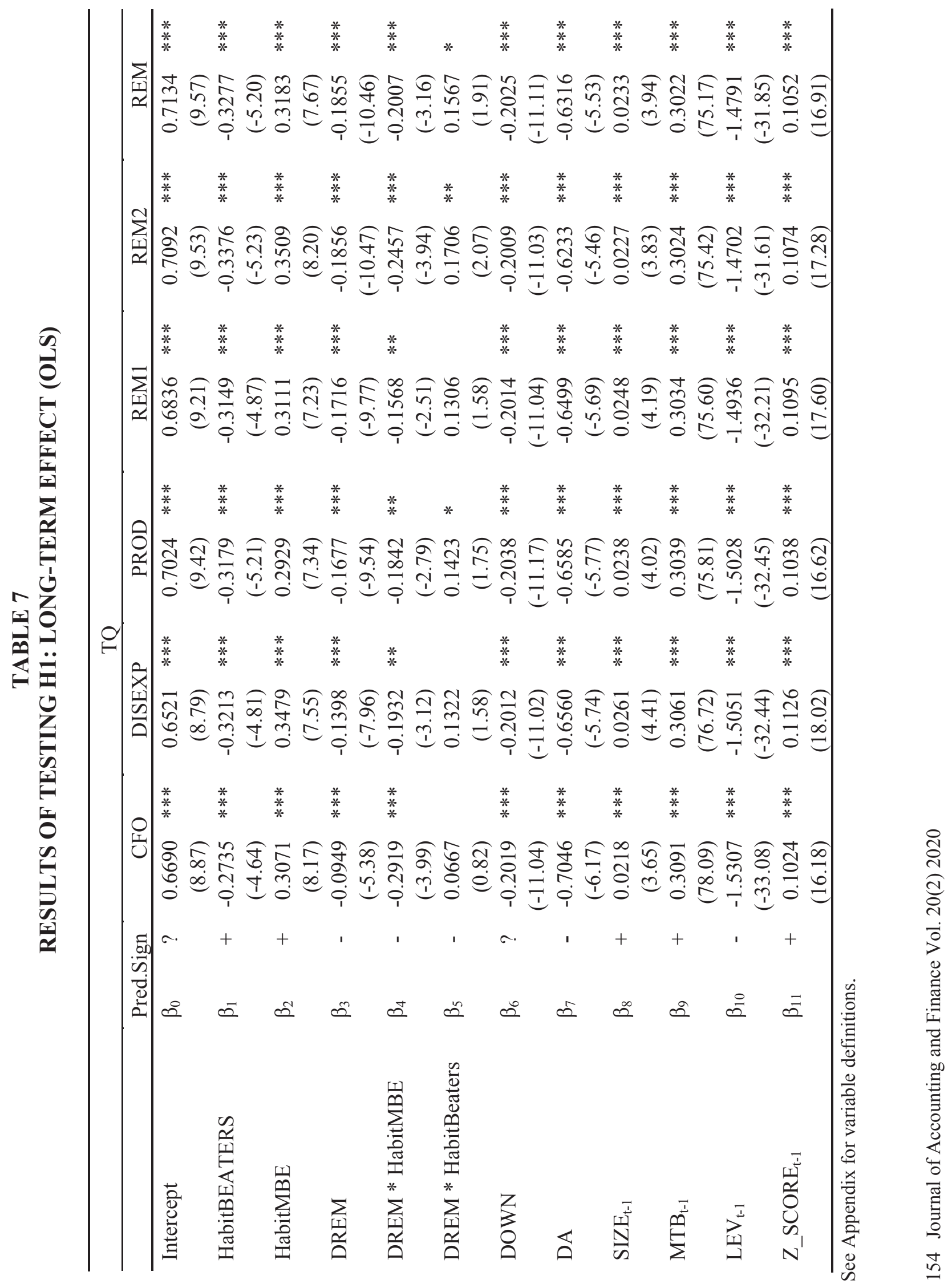




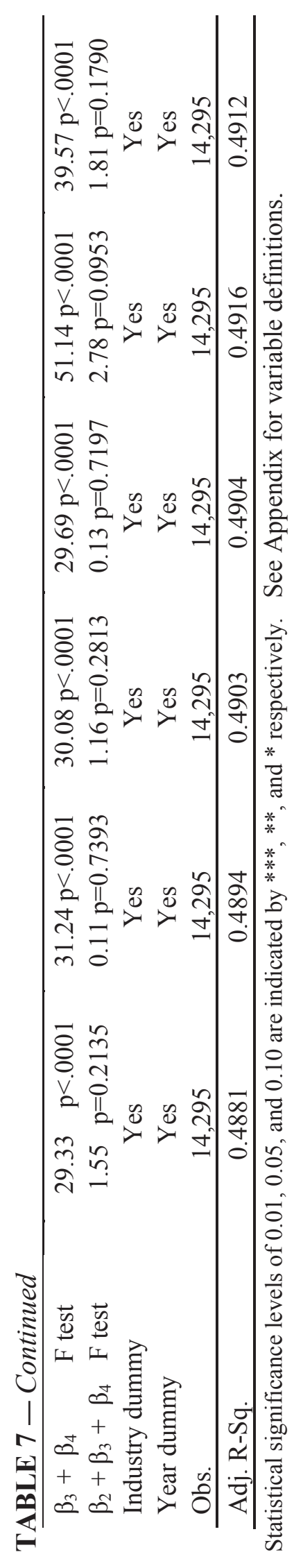


HabitMBE firms enjoy a significant market premium. For instance, in the case of REM_CFO regression, the coefficient of HabitMBE $\left(\beta_{2}\right)$ is 0.3071 , significant at a 0.01 significance level. REM $\left(\beta_{3}\right)$ coefficients are all negative and statistically significant across all six regressions. It seems that incomeincreasing REM activities decrease firms' market value, consistent with the statement from Gunny (2005) that analysts can see through all managerial myopic activities, and also consistent with the statement from Graham et al. (2005) that REM can reduce firms' long-term value.

As expected, the interaction terms of all six regressions $\left(\beta_{4}\right)$ are negative, and statistically significant at a minimum significance level of 0.05 , supporting H1. For example, in the case of CFO, the coefficient of $\beta_{4}$ is -0.2919 , statistically significant at a 0.01 significance level, indicating that a HabitMBE firm that uses REM to achieve this reporting goal incurs such a severe penalty from the market that its TQ will be significantly lower than that of the control firms in this study.

The joint signaling effect documented in Gunny (2010) disappears in the context of this study. Gunny (2010) uses different thresholds for managers to meet/beat: avoiding loss or earnings decrease. She does not cover analysts' forecasts as a benchmark, and most differently her study does not consider the effect of habitual behavior of meeting/beating benchmarks. In addition, her dependent variables are accounting based, not market based measure. In her study, she finds and documents that firms that use REM to meet/beat benchmarks exhibit significantly better performance than non-REM firms that miss the targets, jointly signaling to the market that these firms perform better. In this study, the threshold is analysts' earnings forecast. For instance, in the case of CFO regression, the sum of coefficients $\beta_{3}(-0.0949)$ and $\beta_{4}$ $(-0.2919)$ is -0.3868 . The F-test of the sum of $\beta_{3}$ and $\beta_{4}$ shows significant result with an $F$ value of 29.33 , and a p-value $<.0001$, suggesting that if firms use REM to HabitMBE, the capital market can see through managerial REM actions and will assign a severe penalty to these firms.

Considering the use of REM, the market valuation of HabitMBE firms do not fare better than the control group. For example, in the case of DISEXP column, the F-test of the sum of $\beta_{2}, \beta_{3}$, and $\beta_{4}$ result in a value of 0.11 , with a p-value of 0.7393 . In summary, the market premium HabitMBE firms enjoy disappears. The results hold for all individual REM and aggregate REM measures.

Interesting and important finding is the sign and statistical significance of the coefficient of DOWN $\left(\beta_{6}\right)$ all across the six regressions. They are all negative and statistically significant at a 0.01 significance level. However, Bhojraj et al. (2009) state that although earnings forecast guidance shifts the timing of the earnings surprise, it does not affect future profitability of firms since no economic construct has changed and is therefore strictly a reporting strategy. Analysts' downward forecast revision could be due to their pessimism about firms' future. Kross et al. (2011) find that firms with consistent MBE provide more frequent and pessimistic management forecasts than other firms. This implies that managers of these firms having achieved consistent MBE are more likely to guide the market's expectations downward to avoid breaking their string of MBE. Following the above argument, it is logical to reason that the market will assign a severe penalty to firms that receive analysts' downward forecast revisions in the long run.

All six DA $\left(\beta_{7}\right)$ coefficients are negative and statistically significant at a 0.01 significance level. All six SIZE $\left(\beta_{8}\right)$, MTB $\left(\beta_{9}\right)$, and Z_SCORE $\left(\beta_{11}\right)$ coefficients are positive and statistically significant at a 0.01 significance level, consistent with the results from correlation table and prior studies. Since LEV $\left(\beta_{10}\right)$ is a proxy of firms' risk, the market will assign a negative value to the risk. Therefore, it makes sense that LEV is negative and all statistically significant, also consistent with the results from prior studies.

The coefficients for industry dummies and year dummies are not reported in Table 7. All the years are significantly positively associated with the TQ except two years 2002 and 2008, which are significantly negatively associated with the TQ. It is very likely that Sarbanes-Oxley Act in 2002 and the financial crisis in 2008 had some negative impact on firms' TQ. Of all the 27 industries, only SIC 13 (Oil \& Gas Extraction), the manufacturing industry (SIC 26, 28, 35, 36, 38), SIC 58 (Eating \& Drinking Places), SIC 73 (Business Services), SIC 79 (Amusement \& Recreation Services), and SIC 80 (Health Services) are significantly positively associated with the TQ.

To ensure that multi-collinearity does not bias the results of the study, I obtain the variance inflation factors (VIF) for the independent variables. Most independent variables have VIFs that are just above 
1.00 , with a few above 2.00, and the highest VIF is 2.67 , well below the cutoff value of 10 (Wooldridge, 2009 ), indicating the multi-collinearity is not a problem in this model.

The results from this study have revealed the effective monitoring function of financial analysts. Gunny (2005) documents that analysts can see through all managerial myopic actions. Analysts play an important role in the capital market in guiding investors' investment and monitoring managers' reporting behavior. If REM is detrimental to firms' long-term value as alleged by some executives in Graham et al. (2005), the market will assign a penalty to firms using REM to meet/beat certain reporting goals, as evidenced in this paper and prior accounting literature (e.g., Bhojraj et al., 2009).

The effective monitoring function of financial analysts can also relieve some concerns of the regulators with regard to the expectation games played between management teams and financial analysts. Sankaraguruswamy and Sweeney (2005) build a model to show a symbiotic relationship between the management teams and the analysts. They state that management and analysts jointly want to build a relationship that will help each other, i.e., analysts will let managers achieve the meeting/beating goals, but not much to the extent that will humiliate the analysts. In case of HabitMBE, it seems that management and the analysts live in harmony. Management teams achieve their goals and the analysts do not lose face by missing too much. In this case, the market interprets firms as less risky, and more predictable. However, if HabitMBE firms resort to REM to achieve the reporting goal, financial analysts will interpret that value-reducing action to the market, breaking the harmony and curbing managerial REM actions.

Table 8 presents the result of $\mathrm{H} 2$ whether HabitMBE exhibit REM behavior. It appears that HabitMBE firms do not exhibit any evidence of income-increasing REM activities, since five of the six REM measure coefficients are significantly negatively associated with HabitMBE, supporting H2. However, it appears that HabitBEATERS do exhibit some evidence of income-increasing REM activities, since five of the six REM measure coefficients are significantly positively associated with HabitBEATERS. As mentioned earlier, the interpretation of the results for HabitBEATERS could be misleading. 


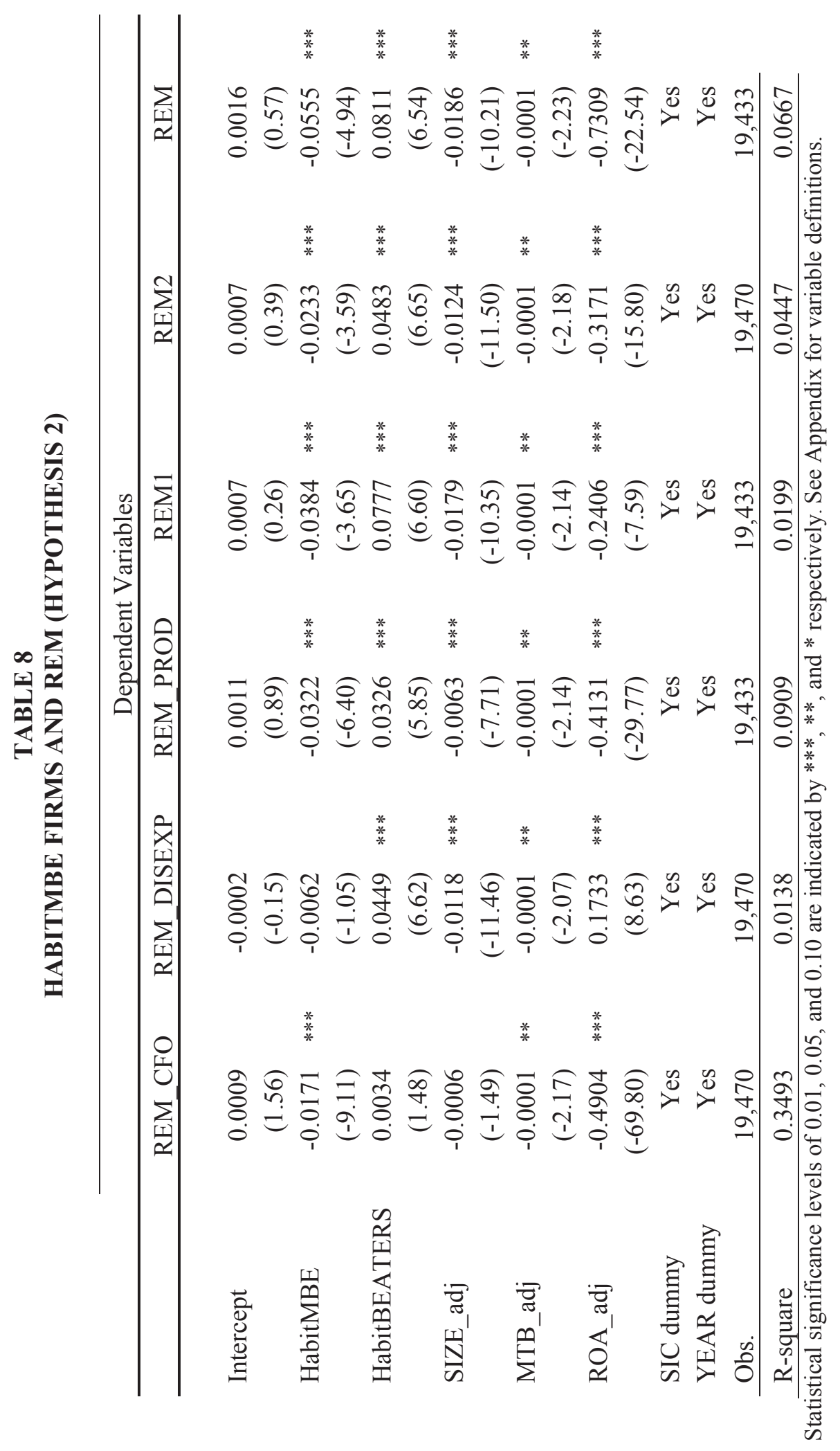


The signs and significance of other variables are also consistent with the results from the correlation matrix table. Since SIZE is a market measure of equity, all coefficients of SIZE are negative, and five of the six coefficients are statistically significant at the 0.01 significance level. MTB is a market measure of growth, and all six coefficients are all statistically negatively significant at the 0.05 significance level. Consistent with the results from the correlation table, REM_DISEXP is statistically positively associated with industry-year adjusted ROA, and all the other five REM measures are all statistically negatively associated with industry-year adjusted ROA.

Preliminary evidence seems to suggest that investors and financial analysts can see through managerial REM actions. Gunny (2005) states that it appears that investors can recognize the future earnings implications of myopic investment in SG\&A and cutting prices and/or overproducing to increase current period income, but they are not able to recognize the future earnings implications of myopic investment in R\&D and the strategic timing of asset sales. It seems that financial analysts are able to recognize the future earnings implications of all four types of REM actions in her study.

Analysts' ability to see through is related to their inclination to cover a firm and their effort to follow a firm. Barth et al. (2001) predict and find that analysts have greater incentives to cover firms with more intangible assets. They also find that analyst coverage is increasing in firm size, growth, trading volume, equity issuance, and perceived mispricing, and is decreasing in the size of firm's analysts' brokerage houses and the effort analysts expend to follow the firm. Duru and Reeb (2002) find that greater corporate international diversification is associated with less accurate and more optimistic forecasts. They suggest that international diversification increases the difficulty in analysts' forecasts, and the forecast process becomes more complex.

Gunny (2010) finds a joint signaling effect from the bench firms. The joint signaling effect states that those bench firms utilize REM actions to signal the capital market firms' bright future performance. In her study, the bench firms are much bigger than any other categories by size. Consistent with her findings, the HabitMBE firms in this study are much bigger firms than any other two categories in terms of AT, SALE, and SIZE. Following the discussion from Barth et al. (2001), size is positively associated with analyst following and coverage, and these firms' earnings should be more stable and more predictable. These analyses will further substantiate the results from the correlation table that HabitMBE firms have the lowest analysts' downward forecast revision.

Consistency is more important than accuracy in analysts' career development (Hilary and Hsu, 2013). The symbiotic relationship between analysts and the management teams makes the earnings forecasts more stable and predictable, and both parties prefer that kind of equilibrium (Sankaraguruswamy and Sweeney, 2005). Income-smoothing literature also supports the idea that management prefers more stable and predictable earnings. Hence, the forecasting process becomes less difficult (Barth et al., 2001), and analysts do not have to spend more effort in following these firms. As a consequence, more analysts will follow these firms, making the "seeing through" more easily, and the firms become more transparent. As Gunny (2005) concludes, analysts can recognize all REM actions of the management teams. Therefore, for these more stable and more predictable firms, if they resort to any REM actions in the reporting process, the market will be able to feel the actions. This argument leads us to the conjecture that these firms will be very cautious in applying REM, and if they ever do so, the market will assign a severe penalty to them.

\section{Additional Tests}

I perform the following tests to check the robustness of my results:

Table 9 presents the results from a Fixed Effects model. Hausman and Taylor (1981) state that fixed effects model is effective in alleviating endogeneity issues. Table 9 presents the results of using the fixed effects model. The results in general are consistent with those reported in the OLS regression in Table 7. The only notable difference is the significance on the coefficients of SIZE $\left(\beta_{8}\right)$. They are still positive and not significant any longer in the fixed effects model. 


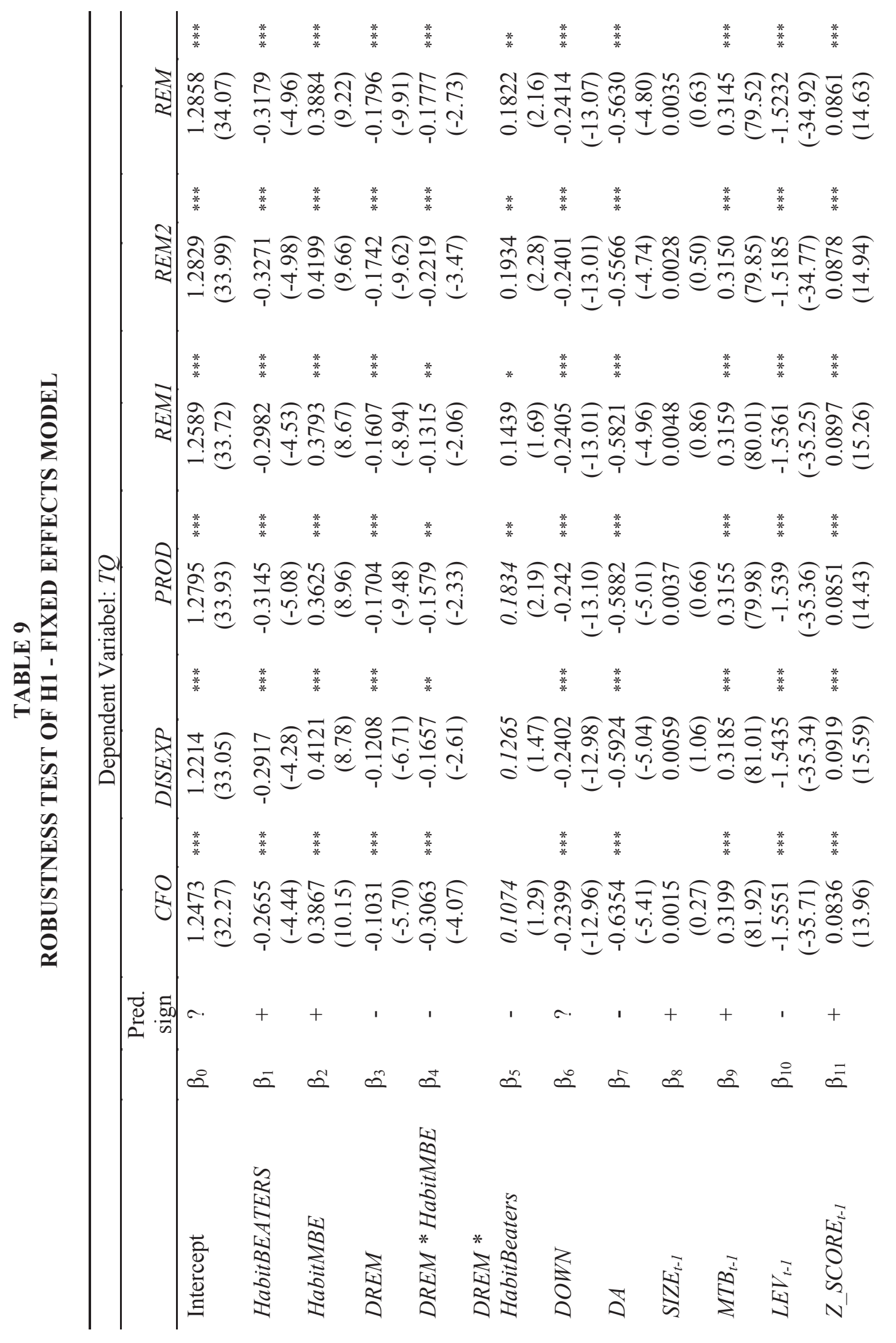




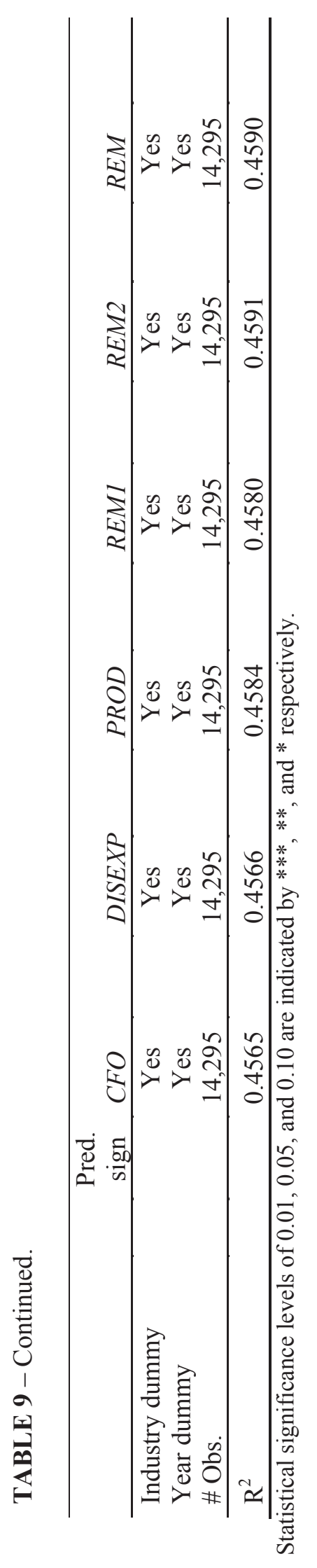

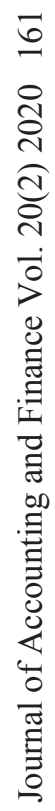


To alleviate potential problems caused by non-independent observations in different categories, I run the regression following Petersen (2009). Table 10 displays the results. The main conclusion still holds. The two differences from the OLS results (Table 7) are the significances in DREM*HabitBEATERS $\left(\beta_{5}\right)$ and SIZE $\left(\beta_{8}\right)$. The significance in $\beta_{5}$ is more pronounced than that in Table 7 . As mentioned earlier, the interpretation on $\beta_{5}$ tends to be misleading in this study. The coefficients on SIZE are positive but not significant as in Table 9 but different from Table 7. The coefficients are the same for Table 9 and Table 10. Differences lie in the t-value of each coefficient. 


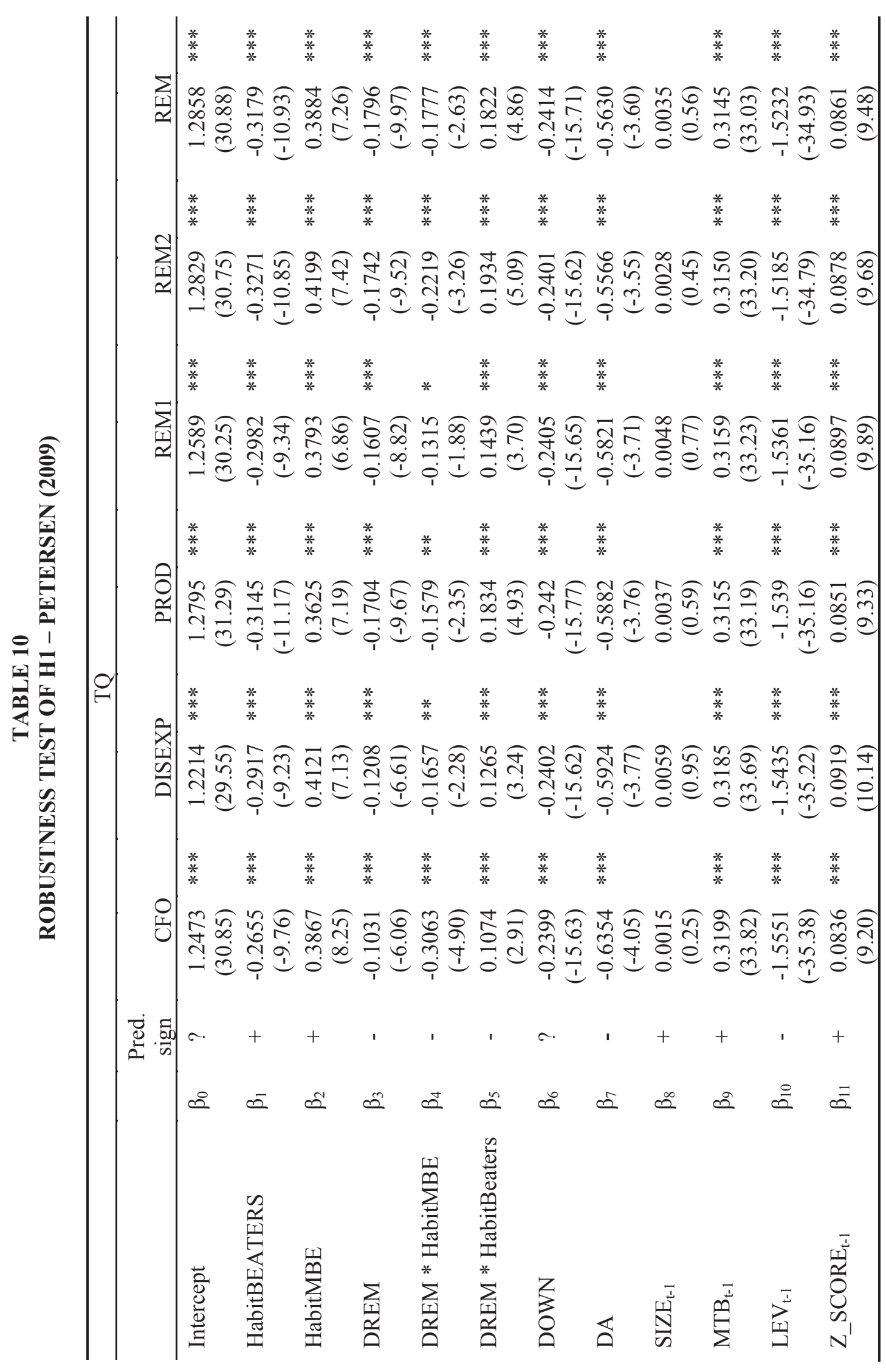

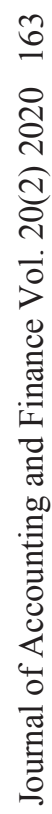




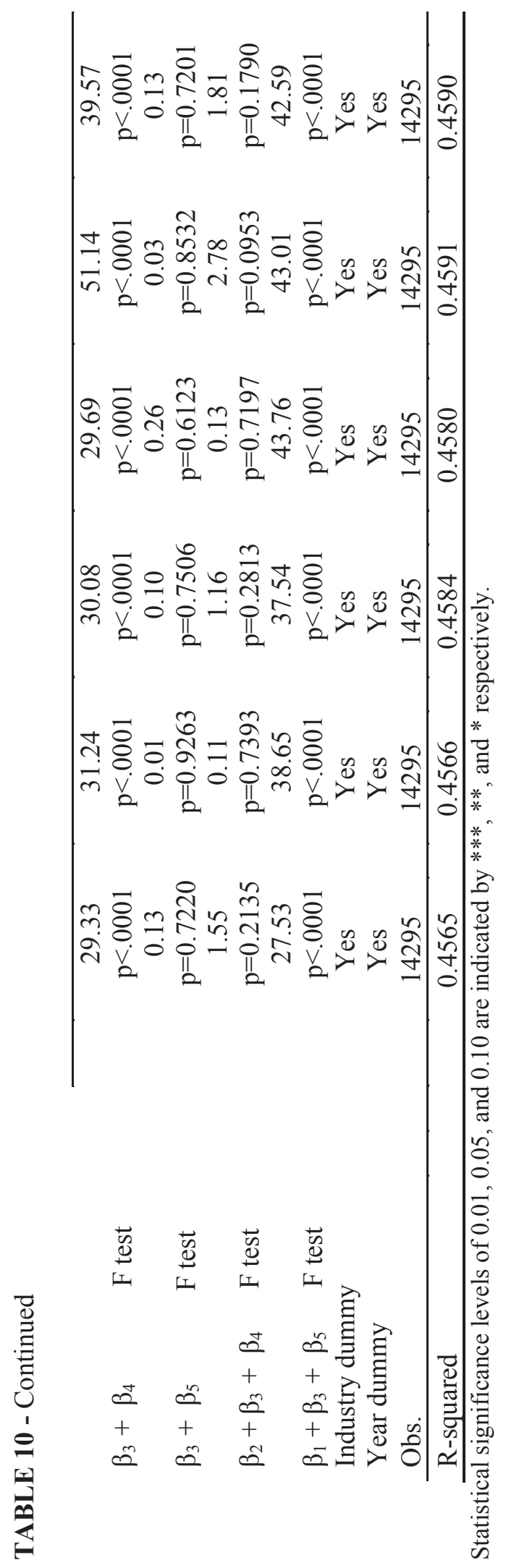


Besides AEM, accounting literature also explores the balance sheet constraints in earnings management. Barton and Simko (2002) predict and find that managers' ability to optimistically bias earnings decreases with the extent to which the balance sheet overstates net assets relative to a neutral application of GAAP. Following Badertscher (2011), I name it BLOAT in this study. Consistent with DA measure, I get the adjusted BLOAT (BLOAT $\mathrm{Bdj}_{\text {dj }}$ ) by subtracting industry-year mean of BLOAT from firmyear specific BLOAT. In the valuation test, I substitute BLOAT adj $_{\text {for }}$ DA.

I define BLOAT as the beginning of net operating assets (NOA) in year $t$ divided by the beginning sales in year t. NOA is equal to the operating assets minus operating liabilities. Operating assets equal total assets (\#AT) minus cash and short-term investment (\#CHE). Operating liabilities equal total assets (\#AT) minus short-term debt (\#DLC) minus long-term debt (\#DLTT) minus minority interest (\#MIB) minus preferred stock (\#PSTK) minus common equity (\#CEQ).

Table 11 presents the valuation results using the BLOAT measure instead of the DA measure. 


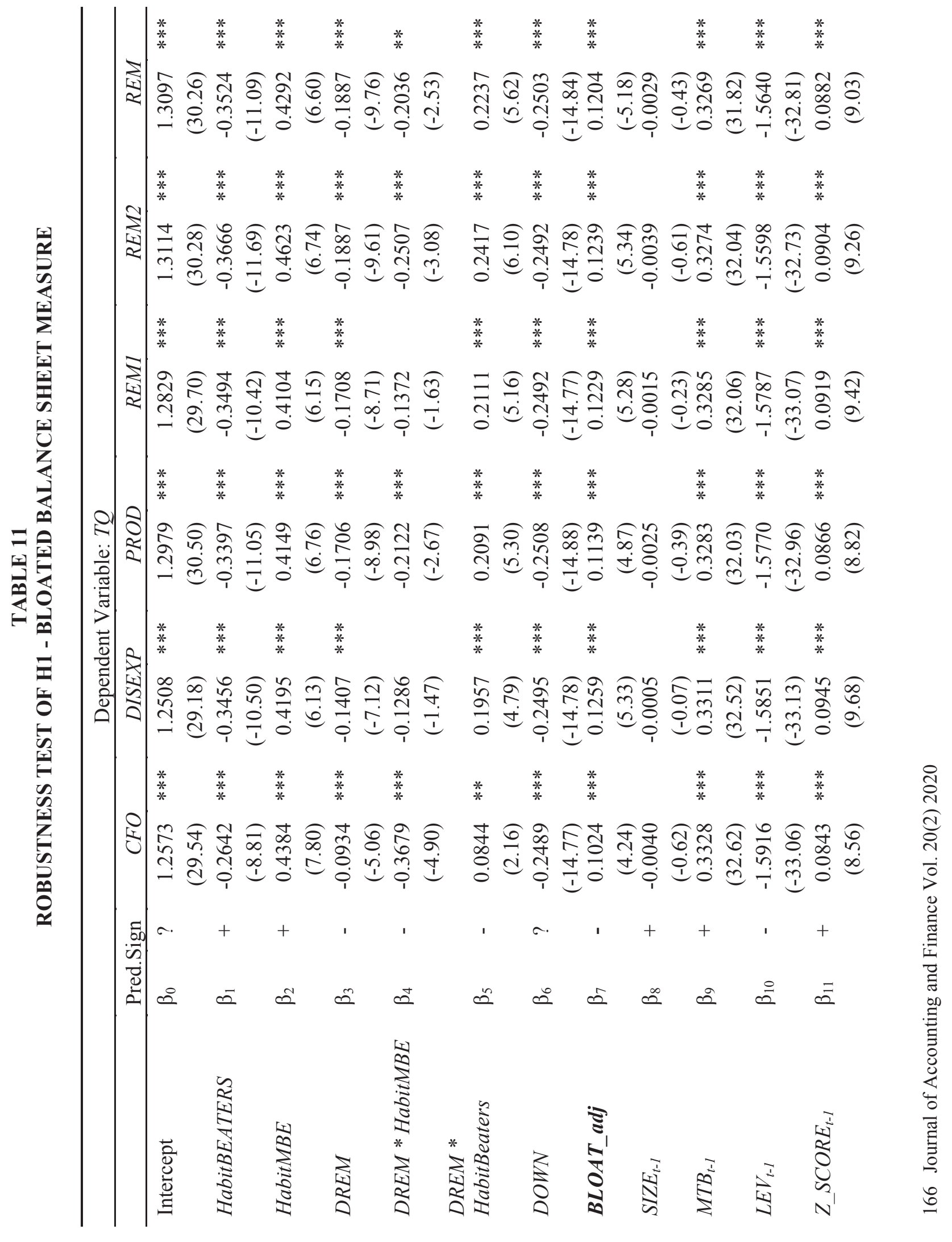




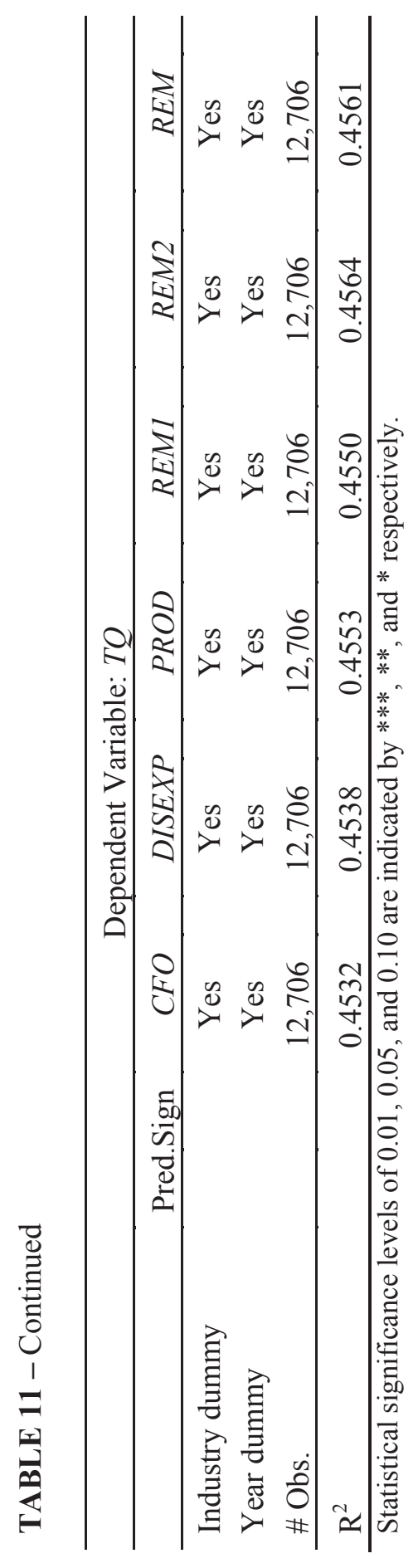

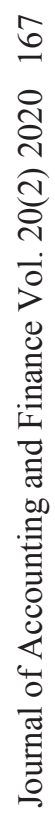


The results from this test are in general consistent with the results when using DA as the control variable. However, the coefficients on $\mathrm{BLOAT}_{\text {adj }}$ are all positive and significant at a 0.01 significance level, different from the results when using DA as a control variable. I was expecting this coefficient to be negative since it is much similar to DA in the sense that the higher the value, the higher the magnitude of upward earnings management. The positive signs might suggest that the market is not able to see through the BLOAT measure as it is able to see through the AEM (DA) measure.

Beneish et al. (2013) develop a model (forensic accounting model) to calculate a score that predicts firms' probability of earnings manipulation. Hereafter, I call this score M_SCORE. To be consistent with the measure of DA, I take the adjusted M_SCORE (M_SCORE $a$ ajj) as firm-year specific M_SCORE minus industry-year mean of M_SCORE. In the valuation test, I substitute M_SCORE $E_{\text {adj }}$ for DA as a control variable.

The calculation of M_SCORE is as follows:

$$
\begin{aligned}
\text { M_SCORE }= & -4.84+0.920(\mathrm{DSR})+0.528(\mathrm{GMI})+0.404(\mathrm{AQI}) \\
& +0.892(\mathrm{SGI})+0.115(\mathrm{DEPI})-0.172(\mathrm{SGAI}) \\
& +4.679(\mathrm{ACCRUALS})-0.327(\mathrm{LEVI})
\end{aligned}
$$

Table 12 presents the results when M_SCORE $E_{\text {adj }}$ is used as a control variable instead of DA. 


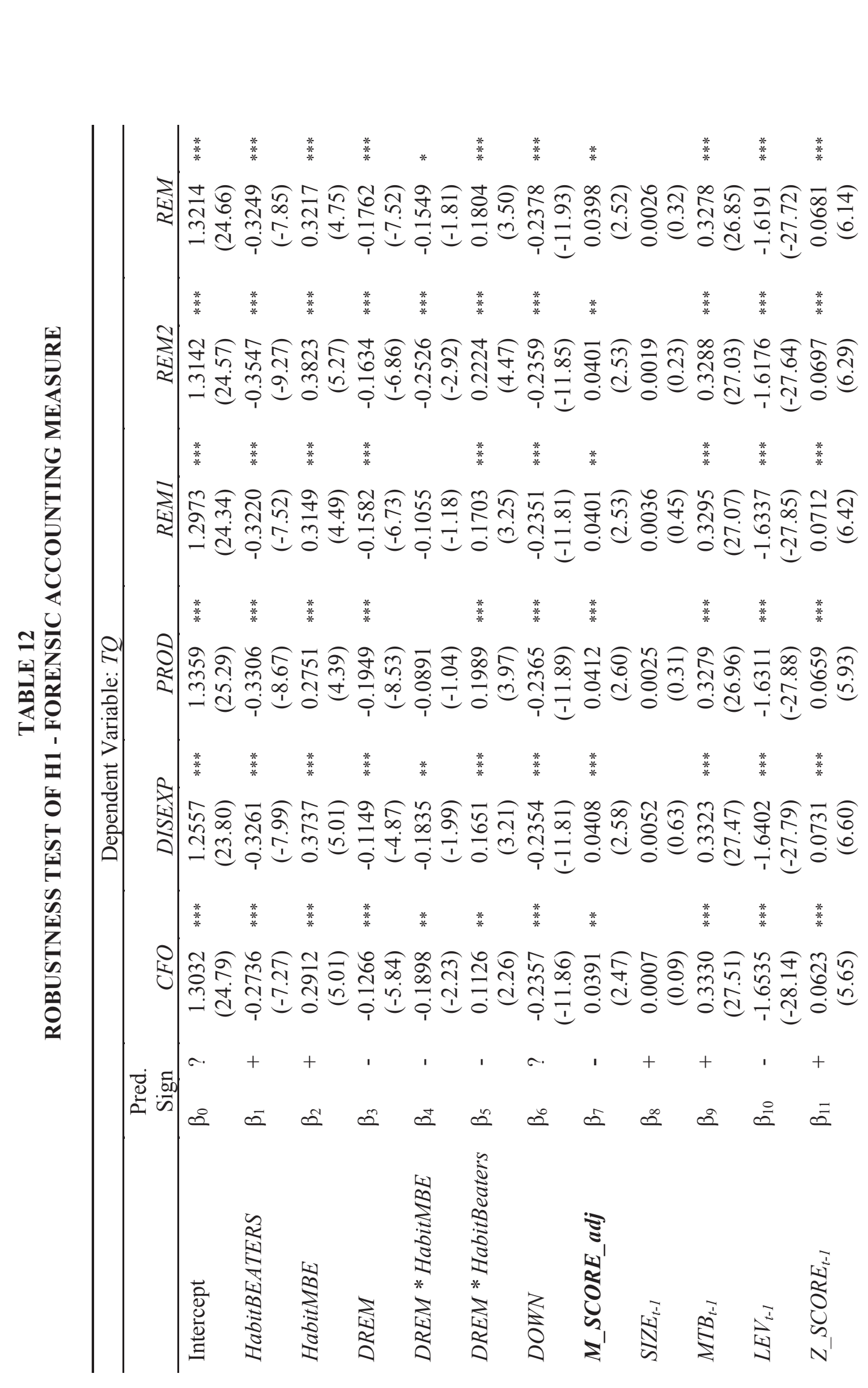

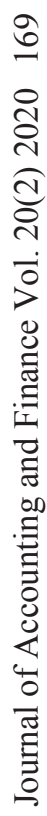




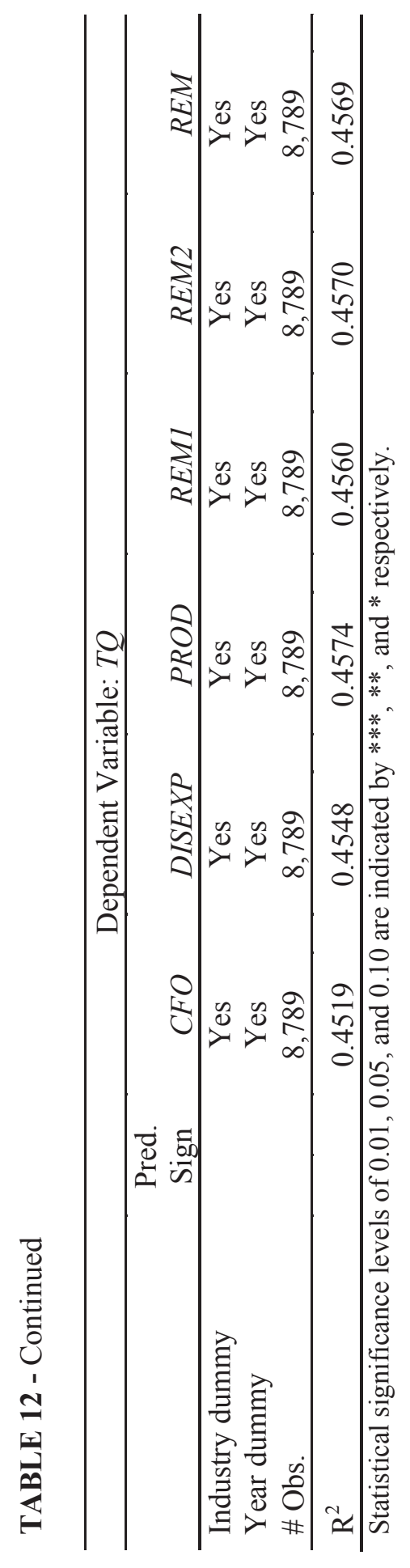

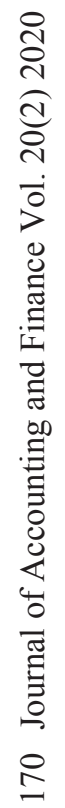


The results, in general, are consistent with those when DA is used as a control variable. However, the coefficients of M_SCOREadj are all positive and significant at least at a 0.05 significance level, different from the results when DA as the control variable. I was expecting this coefficient to be at least negative since M_SCORE functions as DA in the sense that the higher the score, the higher the magnitude of the earnings management. The positive signs might suggest that the market is not able to see through the BLOAT measure as it is able to see through the AEM (DA) measure.

Table 13 presents the results using performance-matching technique suggested by Kothari et al. (2005). I match HabitBEATERS and HabitMBE from the Other group based on industry, year, and closest ROA. For the 1,292 HabitMBE observations, I find 1,263 matching observations. For the 772 HabitBEATERS, I find 722 matching observation in the Other group. After lagging variables, I have 2,313 valid observations for the performance-matching regression. 


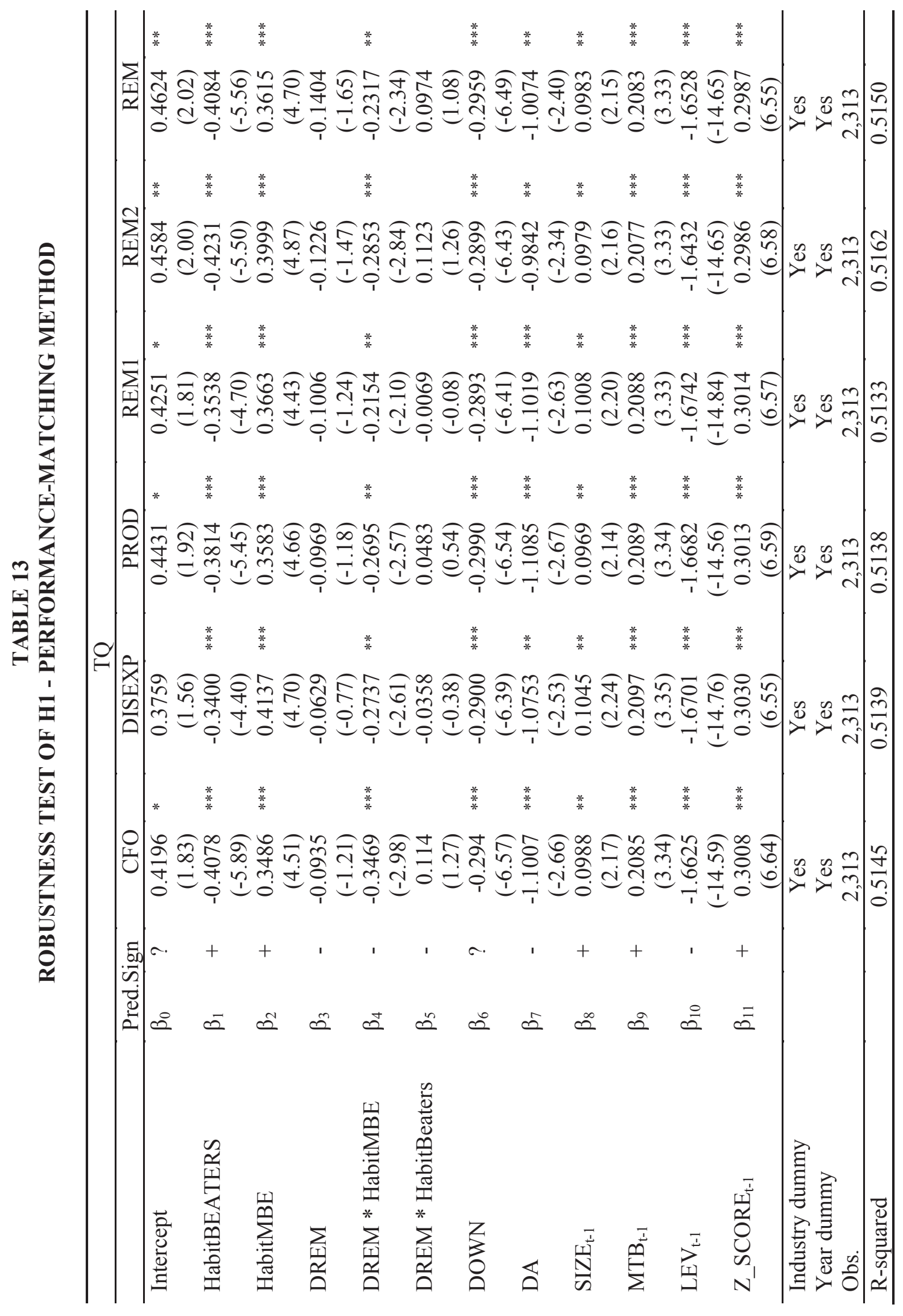

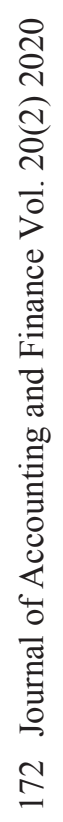


The results, in general, are consistent with the results from OLS regression in Table 8. Notable differences are as follows. The coefficients of DREM $\left(\beta_{3}\right)$ are still negative but not statistically significant any more. The coefficients of DREM*HabitBEATERS $\left(\beta_{5}\right)$ are most (four out of six) positive, but not significant any more.

The robustness tests in aggregate support the predictions of $\mathrm{H} 1$ : as Habit firms tend to use REM to achieve the reporting goals, the market premium assigned to them disappears, supporting the effective monitoring function of financial analysts.

\section{CONCLUSIONS}

This paper studies the association between utilizing real earnings management to habitually meet/closely beat analysts' forecasts and firm valuation. Results first show that if firms engage in valuereducing REM repeatedly to meet/closely beat analysts' forecasts, analysts and investors can see through the managerial actions and will assign a severe penalty to these firms. Further analyses reveal that HabitMBE firms use less income-increasing REM. HabitMBE firms are larger and are more transparent than any other categories in the study. Capital markets interpret the transparency as less risky and more stable, hence assign a significant premium to these firms for consistently meeting/closely beating analysts' earnings forecasts. In addition, results suggest that analysts' downward forecast revisions have significant and negative effect on firm valuation, which prior studies have not documented clearly.

This paper contributes to the REM literature and the managerial reporting behavior literature. Specifically, this paper studies REM and MBE jointly, filling a gap by analyzing the relation between using REM to habitually MBE and firm valuation. MBE, even habitual meeting/beating analysts' forecasts, has been studied in the accounting literature, but has been largely done from the perspectives of accruals earnings management or expectations earnings management. REM has been studied in the accounting literature as well, but has been scarcely examined as a way to MBE, much less Habitual MBE. Several studies, including survey and empirical ones, explore the relation between REM and firms' performance, but the relation between using REM to habitually MBE and firm valuation has not yet been explored.

This paper has some implications to the regulators, investors, and financial analysts. Regulators have expressed their concerns about the expectation games played between corporate managers and financial analysts. It seems that neither the managers nor the financial analysts are doing their jobs but playing games to stay employed. However, the results of the study suggest that financial analysts are doing their jobs to monitor managers' myopic reporting behavior. If managers repeatedly use REM to meet/closely beat analysts' earnings forecasts, analysts will convey that information to the investors, and investors will take punitive actions to warn the managers of their myopic behavior.

\section{REFERENCES}

Anderson, R. C., \& Reeb, D. M. (2003). Founding-family ownership and firm performance: Evidence from the S\&P 500. Journal of Finance, 58(3), 1301-1328.

Antle, R., \& Smith, A. (1986). An empirical investigation of the relative performance evaluation of corporate executive. Journal of Accounting Research, 24(1), 1-39.

Badertscher, B. A. (2011). Overvaluation and the choice of alternative earnings management mechanisms. Accounting Review, 86(5), 1491-1518.

Barber, B. M., \& Lyon, J. D. (1996). Detecting abnormal operating performance: the empirical power and specification of test statistics. Journal of Financial Economics, 41(3), 359-399.

Barth, M. E., Kasznik, R., \& McNichols, M. F. (2001). Analyst coverage and intangible assets. Journal of Accounting Research, 39(1), 1-34.

Barton, J., \& Simko, P. J. (2002). The balance sheet as an earnings management constraint. Accounting Review, 77(s-1), 1-27. 
Bartov, E. (1993). The timing of asset sales and earnings manipulation. Accounting Review, 68(4), 840855.

Bartov, E., Givoly, D., \& Hayn, C. (2002). The rewards to meeting and beating earnings expectations. Journal of Accounting and Economics, 33, 173-204.

Beneish, M. D. (2001). Earnings management: A perspective. Managerial Finance, 27(12), 3-17.

Beneish, M. D., Lee, C. M. C., \& Nichols, D. C. (2013). Earnings manipulation and unexpected returns. Financial Analysts Journal, 69(2), 57-82.

Bhojraj, S., Hribar, P., Picconi, M., \& McInnis, J. (2009). Making sense of cents: an examination of firms that marginally miss or beat analyst forecasts. Journal of Finance, 64(5), 2361-2388.

Brown, L. D., \& Caylor, M. L. (2005). A temporal analysis of quarterly earnings thresholds: propensities and valuation consequences. Accounting Review, 80(2), 423-440.

Brown, L. D., Hagerman, R. L., \& Griffin, P. A. (1987). Security analyst superiority relative to univariate time-series models in forecasting quarterly earnings. Journal of Accounting and Economics, 9(1), 61-87.

Brown, L. D., \& Pinello, A. S. (2007). To what extent does the financial reporting process curb earnings surprise games? Journal of Accounting Research, 45(5), 947-981.

Burgstahler, D., \& Dichev, I. (1997). Earnings management to avoid earnings decreases and losses. Journal of Accounting and Economics, 24(1), 99-126.

Burgstahler, D., \& Eames, M. (2006). Management of earnings and analysts' forecasts to achieve zero and small positive earnings surprises. Journal of Business Finance \& Accounting, 33(5-6), $633-$ 652.

Cheng, Q., \& Warfield, T. D. (2005). Equity incentives and earnings management. Accounting Review, 80(2), 441-476.

Cohen, D. A., Dey, A., \& Lys, T. Z. (2008). Real and accrual-based earnings management in the pre- and post-Sarbanes-Oxley periods. Accounting Review, 83(3), 757-787.

Cohen, D. A., \& Zarowin, P. (2010). Accrual-based and real earnings management activities around seasoned equity offerings. Journal of Accounting and Economics, 50(1), 2-19.

Dechow, P., Richardson, S. A., \& Tuna, I. (2003). Why are earnings kinky? An examination of the earnings management explanation. Review of Accounting Studies, 8, 355-384.

Degeorge. F., Patel, J., \& Zeckhauser, R. (1999). Earnings management to exceed thresholds. Journal of Business, 72(1), 1-33.

Demski, J. S., \& Feltham, G. A. (1978). Economic incentives in budgetary control systems. Accounting Review, 53, 336-359.

Duru, A., \& Reeb, D. M. (2002). International diversification and analysts' forecast accuracy and bias. Accounting Review, 77(2), 415-433.

Evans, J. H., \& Sridhar, S. S. (1996). Multiple control systems, accrual accounting, and earnings management. Journal of Accounting Research, 34(1), 45-65.

Fields, T. D., Lys, T. Z., \& Vincent, L. (2001). Empirical research on accounting choice. Journal of Accounting and Economics, 31(1-3), 255-307.

Graham, J. R., Harvey, C. R., \& Rajgopal, S. (2005). The economic implications of corporate financial reporting. Journal of Accounting and Economics, 40, 3-73.

Gul, F. A., Leung, S., \& Srinidhi, B. (2002). Informative and opportunistic earnings management and the value relevance of earnings: Some evidence of the role of IOS. Available at SSRN 429800, 2003 - papers.ssrn.com.

Gunny, K. (2005). What are the consequences of real earnings management? Working paper.

Gunny, K. (2010). The relations between earnings management using real activities manipulation and future performance: evidence from meeting earnings benchmarks. Contemporary Accounting Research, 27(3), 855-888.

Harris, M., \& Raviv, A. (1979). Optimal incentive contracts with imperfect information. Journal of Economics Theory, 24, 231-259. 
Hausman, J. A., \& Taylor, W. E. (1981). Panel data and unobservable individual effects. Econometrica, 49, 1377-1398.

Healy, P. M. (1985). The effect of bonus schemes on accounting decision. Journal of Accounting and Economics, 7(1-3), 85-107.

Hilary, G., \& Hsu, C. (2013). Analyst forecast consistency. Journal of Finance, 68, (1), 271-297.

Jones, J. J. (1991). Earnings management during import relief investigations. Journal of Accounting Research, 29(2), 193-228.

Kaplan, S. N. \& Zingales, L. (1997). Don investment-cash flow sensitivities provide useful measures of financing constraints? Quarterly Journal of Economics, 169 - 215.

Kasznik, R., \& McNichols, M. F. (2002). Does earnings expectations matter? Evidence from analyst forecast revisions and share prices. Journal of Accounting Research, 40(3), 727-759.

Kothari, S. P., Leone, A. J., \& Wasley, C. E. (2005). Performance matched discretionary accrual measures. Journal of Accounting and Economics, 39, 163-197.

Kross, W. J., Ro, B. T., \& Suk, I. (2011). Consistency in meeting/beating the market's expectations and management earnings forecasts. Journal of Accounting and Economics, 51(1-2), 37-57.

Levitt, A. (1998). The "numbers game". NYU Center for Law and Business, New York, N. Y.

Matsumoto, D. A. (2002). Management's incentives to avoid negative earnings surprises. Accounting Review, 77(3), 483-514.

Mirrlees, J. (1976). The optimal structure of incentives and authority within an organization. Bell Journal of Economics, 7, 105-131.

Payne, J. L., \& Thomas, W. B. (2003). The implications of using stock-split adjusted I/B/E/S data in empirical research. Accounting Review, 78(4), 1049-1067.

Petersen, M. A. (2009). Estimating standard errors in finance panel data sets: Comparing approaches. Review of Financial Studies, 22(1), 435-480.

Roychowdhury, S. (2006). Earnings management through real activities manipulation. Journal of Accounting and Economics, 42, 335-370.

Sankaraguruswamy, S., \& Sweeney, R. J. (2005). Available at SSRN 683041, 2005-papers.ssrn.com

Schipper, K. (1989). Commentary on earnings management. Accounting Horizon, 3(4), 91-102.

Skinner, D. J., \& Sloan, R. G. (2002). Earnings surprises, growth expectations, and stock returns. Review of Accounting Studies, 7, 289-312.

Wooldridge, J. M. (2009). Introductory Econometrics: A Modern Approach, $5^{\text {th }}$ edition. Mason, OH: South-Western Cengage Learning.

Yermack, D. (1996). Higher market valuation of companies with a small board of directors. Journal of Financial Economics, 40(2), 185-211.

Zang, A. Y. (2012). Evidence on the trade-off between real activities manipulation and accrual-based earnings management. Accounting Review, 87(2), 675-703. 


\section{APPENDIX}

\section{Variable Measurement}

\begin{tabular}{ll}
\hline TAt & $=$ \\
At-1 & $=$ \\
St & $=$ \\
$\Delta$ St & $=$ \\
$\Delta$ St-1 & $=$ \\
PPEt & $=$ \\
CFOt & $=$ \\
PRODt & $=$ \\
DISEXPt &
\end{tabular}

$\begin{array}{ll}\text { ABN_CFOt } & = \\ \text { ABN_DISEXPt } & = \\ \text { ABN_PROD t } & = \\ \text { REM_CFOt } & = \\ \text { REM_DISEXPt } & = \\ \text { REM_PRODt } & = \\ \text { REM1 } & = \\ \text { REM2 } & = \\ \text { REM } & = \\ \text { DAt } & = \\ \text { SIZE } & = \\ \text { MTB } & =\end{array}$

Tobin's Q (TQ) = =

HabitBEATERS $\quad=\quad$ habitual beaters, a dummy variable that is equal to 1 if a firm is identified as a habitual beater, by which I mean a firm has beaten the analysts' forecasts by more than one cent at least $50 \%$ of the times during immediate prior years;

HabitMBE $\quad=\quad$ habitual MBE, a dummy variable that is equal to 1 if a firm is identified as a HabitMBE, by which I mean a firm has met or beaten the analysts' forecasts by one cent at least $50 \%$ of times during the immediate prior years;

DREM $\quad=\quad$ a dummy variable that is equal to 1 if REM is greater than zero; otherwise it is equal to zero;

DREM_CFO = a dummy variable that is equal to 1 if REM_CFO is greater than zero; otherwise it is equal to zero;

DREM_DISEXP = $\quad$ a dummy variable that is equal to 1 if REM_DISEXP is greater

DREM_PROD $\quad=\quad \begin{aligned} & \text { than zero; otherwise it is equal to zero; } \\ & \text { a dummy variable that is equal to } 1 \text { if REM_PROD is greater than }\end{aligned}$

zero; otherwise it is equal to zero;

DREM1 = a dummy variable that is equal to 1 if REM1 is greater than zero; otherwise it is equal to zero;

DREM2 = a dummy variable that is equal to 1 if REM2 is greater than zero; otherwise it is equal to zero; 
DOWN $=\quad$ a dummy variable that is equal to 1 if forecast revision (the difference between the most recent consensus forecast just before the earnings announcement and the forecast 30 to 60 days before the fiscal year-end) is negative; otherwise, it is equal to zero;

LEV $\quad=\quad$ leverage, calculated as sum of current liabilities and long-term debt divided by lagged total assets;

Z_SCORE $\quad=\quad$ a measure of financial health, calculated as $3.3 *($ EBIT/At- 1$)$ $+1.0 *(\mathrm{St} / \mathrm{At}-1)+1.4 *(\mathrm{REt} / \mathrm{At}-1)+1.2 *(\mathrm{WCAPt} / \mathrm{At}-1)$

I define BLOAT as the beginning of net operating assets (NOA) in year $t$ divided by the beginning sales in year t. NOA is equal to the operating assets minus operating liabilities. Operating assets equal total assets (\#6) minus cash and short-term investment (\#1). Operating liabilities equal total assets (\#6) minus short-term debt (\#34) minus long-term debt (\#9) minus minority interest (\#38) minus preferred stock (\#130) minus common equity (\#60).

$$
\begin{aligned}
\text { M_SCORE }=\quad & -4.84+0.920(\mathrm{DSR})+0.528(\mathrm{GMI})+0.404(\mathrm{AQI})+0.892(\mathrm{SGI}) \\
& +0.115(\mathrm{DEPI})-0.172(\mathrm{SGAI})+4.679(\mathrm{ACCRUALS})-0.327(\mathrm{LEVI})
\end{aligned}
$$

\begin{tabular}{|c|c|c|}
\hline DSR & $=$ & $\begin{array}{l}\text { (RECEIVABLESt (Data \#2)/SALESt }(\text { Data \#12))/ } \\
\text { RECEIVABLESt-1/SALESt-1); }\end{array}$ \\
\hline GMI & $=$ & $\begin{array}{l}\text { GROSS MARGINt-1/GROSS MARGINt, where GROSS MARGIN = } \\
1 \text { - COGS (Data \#8)/ SALES; }\end{array}$ \\
\hline AQI & $=$ & $\begin{array}{l}{[1-(\mathrm{PPEt}+\mathrm{CAt}) / \mathrm{TAt}] /[1-(\mathrm{PPEt}-1+\mathrm{CAt}-1) / \mathrm{TAt}-1], \text { where PPE is net }} \\
\text { Data }(\# 8), \mathrm{CA} \text { is current asset }(\text { Data } \# 4), \text { and TA is total assets Data }(\# 6)\end{array}$ \\
\hline SGI & $=$ & SALESt (Data \#12)/SALESt-1; \\
\hline DEPI & $=$ & $\begin{array}{l}\text { DEPRECIATION RATEt-1/DEPRECIATION RATEt, Where } \\
\text { depreciation rate = depreciation (Data \#14 -65)/(Depreciation } \\
+ \text { PPE (Data \# 8)); }\end{array}$ \\
\hline SGAI & $=$ & [(SG\&At (Data \#189)/SALESt (Data \#12)]/ [SG\&At-1/SALESt-1]; \\
\hline ACCRUALS & $=$ & $\begin{array}{l}\text { (Income before extraordinary items (Data \#18) - Cash from Operations } \\
(\text { Data \#308))/TAt; }\end{array}$ \\
\hline LEVI & $=$ & $\begin{array}{l}\text { LEVERAGEt/LEVERAGEt-1, where LEVERAGE = debt }(\text { Data \#5 } \\
\text { + Data \#9)/TA; }\end{array}$ \\
\hline
\end{tabular}

where: 